\title{
Effect of soil water-to-air ratio on biomass and mineral nutrition of avocado trees
}

\author{
P.M. Gil ${ }^{1 *}$, C. Bonomelli ${ }^{1}$, B. Schaffer ${ }^{2}$, R. Ferreyra ${ }^{3,4}$ and C. Gentina ${ }^{3}$ \\ ${ }^{1}$ Departamento de Fruticultura y Enología, Facultad de Agronomía e Ingeniería Forestal, Pontificia Universidad \\ Católica de Chile, Casilla 306-22, Santiago, Chile. ${ }^{2}$ Tropical Research and Education Center, University of \\ Florida, 18905 S.W. 280 Street, Homestead, Florida 33031, USA. ${ }^{3}$ Instituto de Investigaciones Agropecuarias \\ (INIA), Chorrillos 85 la Cruz, Chile. ${ }^{4}$ Centro Regional de Estudios para Alimentos Saludables (CREAS) Blanco \\ 1623, Of. 1402, Valparaíso, Chile. ${ }^{*}$ Corresponding author: pmgil@uc.cl
}

\begin{abstract}
In Chile, expansion of avocado production has resulted in many orchards established in marginal soils that are poorly drained and have high soil water-to-air ratios when soil moisture is at field capacity. However, avocado trees are sensitive to poor soil aeration. A study was conducted to determine the effects of different soil waterto-air ratios (W/A) on biomass and nutrient content of avocado trees. Two-yearold avocado trees were grown for 2 seasons in containers in soils, with different W/A, collected from different avocado growing regions of Chile. There were five treatments corresponding to each of the five soils. At field capacity, the two-season average W/A was $1.7,1.3,0.6,0.4$ or 0.3 for treatments T1, T2, T3, T4, or T5, respectively. The same amount of fertilizer was applied to each soil. Mineral element concentrations and total mineral element contents in leaves, shoots, wood and roots were determined for each tree in each treatment at the end of the experimental period. Shoot and root fresh and dry weights, leaf area and leaf retention were also determined. Although all treatments showed non-limiting soil oxygen conditions for avocado root growth, trees in soils with lower W/A had greater shoot and root dry weights and longer autumn leaf retention. Macro- and micronutrient concentrations in any plant tissue were not related to soil W/A. However, total tissue contents of N, $\mathrm{P}, \mathrm{K}, \mathrm{Ca}, \mathrm{Mg}, \mathrm{C}, \mathrm{N}$ and $\mathrm{B}$ in roots and whole plants were highest in treatments with lower soil W/A. The results indicate that soil W/A significantly affects growth and mineral nutrition of avocado trees and should be considered for avocado site selection and management.
\end{abstract}

Keywords: mineral nutrition, nutrient uptake, soil aeration, avocado.

Abbreviations: W/A = soil water-to-air ratio; $\mathrm{q}=$ volumetric soil water content; $\mathrm{ODR}=$ oxygen diffusion rate; $\mathrm{BD}=$ bulk density; $\mathrm{FC}=$ field capacity. 


\section{Introduction}

Commercial avocado production in Chile has expanded to areas with poorly drained soils that are low in oxygen. Studies of soils from five different avocado growing regions in Chile showed that soil macroporosity was directly related to avocado stress responses when soil water content was maintained at or above field capacity (Ferreyra et al., 2007). It was suggested that tree stress responses were directly related to the water-to-air ratios (W/A) in the soil as a result of different macroporosities (Ferreyra et al., 2007). That study established that soil air content lower than $17 \%$ restricts the oxygen diffusion rate to less than $0.2 \mu \mathrm{g}$ $\mathrm{cm}^{-2} \mathrm{~min}^{-1}$ and that macroporosity values are correlated with soil $\mathrm{O}_{2}$ and $\mathrm{CO}_{2}$ contents. According to Valoras et al., (1964), avocado roots cease growing when the oxygen diffusion rate in the soil is below $0.20 \mu \mathrm{g} \mathrm{cm}^{-2} \mathrm{~min}^{-1}$. Also, Stolzy et al., (1967) found that in soils with oxygen diffusion rates below 0.17 $\mu \mathrm{g} \mathrm{cm}^{-2} \mathrm{~min}^{-1}$, 'Mexicola' avocado trees had 44-100\% of their roots damaged. It has been observed that in soils with water content maintained near field capacity, stomatal conductance $(g s)$, transpiration $(T r)$, stem water potential (SWP) and net $\mathrm{CO}_{2}$ assimilation $(A)$ of avocado were higher in soils with low water-to-air ratios compared to those with high water-to-air ratios, although soil oxygen content never reached hypoxic levels (Gil, 2008).

In soils with high clay content that are compacted, saturated or with slow subsurface drainage, an inadequate oxygen concentration in the root zone can negatively affect plant growth and productivity (Letey, 1961). For avocado trees, root hypoxia or anoxia usually results in reductions in $g s, T r$, and $A$, physiological responses that can negatively affect root and shoot growth and leaf expansion (Schaffer and Ploetz,
1989; Schaffer et al., 1992; Schaffer, 1998; Schaffer and Whiley, 2002). Root growth of avocado trees is optimal in well-drained soils with $\mathrm{O}_{2}$ and $\mathrm{CO}_{2}$ contents of $15 \%$ and $0.03 \%$, respectively, whereas root growth is inhibited in poorly aerated soils with $1 \% \mathrm{O}_{2}$ and $16 \% \mathrm{CO}_{2}$ (Menge and Marais, 2000).

Soil susceptibility to compaction is influenced predominantly by its texture, mainly by the clay fraction. Soil texture also affects how well nutrients and water are retained in the soil. Clays and organic soils hold nutrients and water much better than sandy soils (Mengel and Kirkby, 2001). Solute transport from the soil to the root surface also depends on soil moisture, hydraulic conductivity and the tortuosity factor, which are functions of soil texture (Vetterlein et al., 2007) and therefore have an effect on nutrient uptake. Anderson et al., (2007) reported that ${ }^{15} \mathrm{~N}$ uptake in grasses varied in response to soil texture, root biomass and activities of two enzymes (glutamine synthetase and nitrate reductase). In peach trees, it was observed that nitrogen uptake from a course textured soil was more than double that from a fine textured soil, which resulted in greater tree growth in the course textured soil (Scandellari et al., 2010).

Low soil oxygen content has been shown to affect the nutrient element content of avocado trees. For 'Hass' avocado on Duke or Topa Topa rootstocks, growing trees in soil with $2 \%$ oxygen resulted in lower leaf $\mathrm{N}, \mathrm{P}, \mathrm{K}, \mathrm{Ca}, \mathrm{Mn}$ and $\mathrm{Cu}$ contents compared with trees grown in soil with $21 \%$ oxygen (Labanauskas et al., 1978; Slowick et al., 1979). However, leaf Fe content of 'Hass' (Labanauskas et al., 1978) and leaf $\mathrm{Fe}$ and Mn content of seedling 'Mexicola' avocado trees (Stolzy et al., 1967) were higher in trees grown in soil with low oxygen content than in those grown 
in soil with a high oxygen content. This was attributed to $\mathrm{Fe}$ and $\mathrm{Mn}$ being reduced in hypoxic soil to forms that are readily absorbed and metabolized by the trees (Stolzy et al., 1967, Labanauskas et al., 1978).

In avocado roots, $\mathrm{N}, \mathrm{K}$, and $\mathrm{Mg}$ concentrations were higher in trees grown in soil with $2 \%$ oxygen than in soil with $21 \%$ oxygen, whereas $\mathrm{Na}, \mathrm{Cl}$ and $\mathrm{Zn}$ concentrations were higher in soil with low oxygen $(2 \%)$ than in soil with high oxygen (21\%) (Labanauskas et al., 1978).

Although the effects of low soil oxygen content as a result of flooding or low soil aeration have been reported on avocado physiology (Schaffer and Ploetz, 1989; Schaffer, 1998; Schaffer et al., 1992; Schaffer and Whiley, 2002; Gil et al., 2007; Ferreyra et al., 2008), little is known about the effects of soil characteristics related to water-to-air ratios on growth and nutrition uptake of avocado trees. An understanding of the relationship between soil features such as the soil water-to-air ratio on avocado growth and nutrient uptake would provide valuable insight for irrigation and fertilization management of this crop in different soils, particularly in areas with poor soil aeration. The objective of this study was to evaluate the effects of soils with different soil water-to-air ratios on plant biomass, nutrient concentration and total tissue nutrient content of avocado trees.

\section{Materials and methods}

\section{Plant material}

The experiment was conducted from the spring 2005 to the end of the summer 2007, with two-year-old 'Hass' avocado trees grafted onto Mexicola avocado seedling rootstock. Trees were planted in one of five different soils in "containers" with a $65 \mathrm{~cm}$ diameter and $60-65 \mathrm{~cm}$ height ( 200 liters), constructed by mounding field-collected soils and holding mounds in place with a white plastic mesh surrounded by metal wire mesh.

\section{Climatic conditions}

The study site was located outdoors at the Regional Research Center, INIA, in La Cruz, Region of Val-

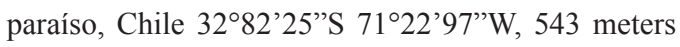
above sea level). La Cruz is located in the Aconcagua Valley with a marine influence. The climate at that location is classified as temperate Mediterranean, specifically, a humid marine Mediterranean climate with an average annual temperature of $14.5^{\circ} \mathrm{C}$, a minimum average temperature of $5.2^{\circ} \mathrm{C}$ (July) and a maximum average temperature of $29.3^{\circ} \mathrm{C}$ (January). The ninemonth period from September to May is frost-free. The average total annual precipitation in the region is $328.5 \mathrm{~mm}$ with $80 \%$ of the precipitation occurring from May to August (Santibañez and Uribe, 1990).

\section{Experimental design}

Five different soils, commonly found in avocado orchards in Chile, were obtained from 5 different fallow fields and hills. Textures and physical characteristics of the soils are shown in Table 1. Soil was steam sterilized and periodically treated with metalaxil and Fosetyl-Al fungicides to prevent root damage from Phytophthora cinnamomi, a common root pathogen in avocado orchards worldwide. Trees were drip irrigated with well water from 16 drippers (low-flow emitters, $0.5 \mathrm{~L} \mathrm{~h}^{-1}$ ) per plant. The irrigation frequency varied from 2 to 6 times per day (according to soil texture and daily evapotranspiration) to maintain relatively constant soil water content near field capacity (soil tension of $-0.33 \mathrm{KPa}$ ). 
Table 1. Physical characteristics, water content and water-to-air ratios (W/A) of five different soil types (treatments; Tmt). Percentages of soil particles represent means obtained from laboratory measurements; other physical feature values represent means obtained from in situ and laboratory measurements. LC = Loam Clay, LS = Loam sandy, $\mathrm{S}=$ Sandy, $\mathrm{FC}=$ field capacity, $\mathrm{BD}=$ bulk density, $\mathrm{P}=$ porosity, $\mathrm{MP}=$ microporosity, $\mathrm{AC}=$ Air capacity.

\begin{tabular}{|c|c|c|c|c|c|c|c|c|c|}
\hline Tmt & $\begin{array}{c}\text { Texture Class } \\
\text { (\% Sand-\% } \\
\text { Silt-\% Clay) }\end{array}$ & $\begin{array}{c}\text { BD } \\
\left(\mathrm{g} \mathrm{cm}^{-3}\right)\end{array}$ & $\begin{array}{c}\text { FC } \theta \\
(\%)\end{array}$ & $\begin{array}{c}P \\
(\%)\end{array}$ & $\begin{array}{l}\text { MP } \\
(\%)\end{array}$ & $\begin{array}{l}\text { AC } \\
(\%)\end{array}$ & $\begin{array}{c}\text { Average water } \\
\text { content }(\theta \%) \\
2005-2007\end{array}$ & $\begin{array}{c}\text { Average soil } \\
\text { air content } \\
(\theta \%) \\
2005-2007\end{array}$ & $\begin{array}{c}\text { Average soil } \\
\text { water/air ratio } \\
\text { (W/A) 2005- } \\
2007\end{array}$ \\
\hline T1 & $\begin{array}{c}\text { LC } \\
(39.5-25.1- \\
35.4)\end{array}$ & 1.43 & 20.0 & 46.0 & 28.6 & 17.5 & 28.8 & 17.4 & 1.7 \\
\hline $\mathbf{T} 2$ & $\begin{array}{c}\text { LC } \\
(39.2-22.6- \\
38.2) \\
\end{array}$ & 1.49 & 19.6 & 43.8 & 29.2 & 14.6 & 24.4 & 19.5 & 1.3 \\
\hline T3 & $\begin{array}{c}\text { LC } \\
(34.1-37.9-28) \\
\end{array}$ & 1.14 & 20.9 & 57.0 & 23.8 & 33.2 & 22.0 & 35.0 & 0.6 \\
\hline $\mathrm{T} 4$ & $\begin{array}{c}\text { LS } \\
(84.4-5.5- \\
10.1) \\
\end{array}$ & 1.45 & 7.3 & 45.3 & 10.5 & 34.7 & 12.5 & 32.8 & 0.4 \\
\hline T5 & $\begin{array}{c}\mathrm{S} \\
(92-0.5-7.5)\end{array}$ & 1.38 & 12 & 47.9 & 16.5 & 31.4 & 11.2 & 36.8 & 0.3 \\
\hline
\end{tabular}

The volume of water applied daily was the same for all treatments. Irrigation volumes varied from the first season to the second season. During the first season, the volume of water applied daily per plant was 0.6, 1.19, 1.64, 2.09, 2.09, 1.79 and 1.49 liters, for September, October, November, December, January, February and March to August, respectively. The amount of water was calculated according the tree size and local evapotransporation. During the second season, the amount of water increased due to the larger tree size, and thus trees were irrigated with $0.6,1.19,2.46,4.48,5.38$, 4.61 and 3.84 liters per plant per day, for September, October, November, December, January, February and March to August, respectively. The applied water varied in frequency among soil treatments, with the idea of keeping soil at field capacity and to avoid leaching. The amount of leaching was not quantified.

Irrigation water and soil analyses indicated no salt or carbonate problems. During the first season, the nutri- tion program was based on $4.2 \mathrm{~g} \mathrm{~N} /$ plant/week, $0.14 \mathrm{~g}$ $\mathrm{P} /$ plant/week, $1.5 \mathrm{~g} \mathrm{~K} /$ plant/week and $0.05 \mathrm{~g} \mathrm{Mg}$ /plant/ week applied as urea, phosphorous acid, potassium nitrate and magnesium sulfate. Plants were fertilized from October to March. During the second season, the nutrition program was based on $6.3 \mathrm{~g} \mathrm{~N} /$ plant/week, $0.22 \mathrm{~g}$ P/plant/week, $2.3 \mathrm{~g} \mathrm{~K} /$ plant/week and $0.08 \mathrm{~g} \mathrm{Mg}$ /plant/ week, applied as urea, phosphorous acid, potassium nitrate and magnesium sulfate. Plants were also fertilized from October to March. Trees were fertilized according to standard nutrient management practices for avocado orchards during the first years of development without fruit production.

The water content of each soil was maintained near field capacity during the experimental period; each of the 5 soils had different physical characteristics and water-to-air ratios (W/A). Thus, there were five soil treatments (T1-T5) each with different average W/A: T1, trees in heavy loam clay soil with an 
average W/A of 1.7 and an average seasonal soil air content of $17.4 \%$; T2, trees in loam clay soil with an average W/A of 1.3 and an average seasonal soil air content of $19.5 \%$; T3, trees in loam clay soil with higher silt content and average W/A of 0.6 and an average seasonal soil air content of $35.0 \%$; $\mathrm{T} 4$, trees in loam sandy soil with an average W/A of 0.4 and an average seasonal soil air content of $32.8 \%$; and T5, trees in sandy soil with an average W/A of 0.3 and an average seasonal soil air content of $36.8 \%$. Soil textures were determined in a laboratory by the Bouyoucos hydrometer method (Day, 1965). The experimental design was a randomized complete block with 5 single-tree replications per treatment. The soil water content, air content and W/A ratios averaged for the entire experimental periods are shown in Table 1.

\section{Measurements of soil physical proprieties}

Measurements of soil physical proprieties were determined using the same methodology described by Gil (2008) for a concurrent study of soil W/A effects on avocado tree physiology. Soil bulk density (BD) was determined by the cylinder method of Blake and Hartage (1986); final BD values were obtained from in-situ measurements and one laboratory determination. Total soil porosity was calculated as described by Danielson and Sutherland (1986) using a soil real density value of $2.64 \mathrm{~g} \mathrm{~cm}^{-1}$, which is a typical value in most mineral-originated soils (Blake and Hartage, 1986). Soil macroporosity (air capacity) in situ was calculated as described by Ball and Smith (1991). The in-situ value was averaged with a laboratory air capacity measurement obtained using the method described by Carrasco (1997). The soil water content at 'in situ field capacity' (FC) was determined using the method described by Cassel and Nielsen (1986). The FC was also determined once in a laboratory using the method described by Danielson and Sutherland (1986). The in-situ and laboratory measurements were pooled to obtain an average FC value. The volumetric soil water content $(\theta)$ at field capacity was also determined.

The volumetric air content of the soil was calculated as described by Benavides (1994). Volumetric water content was subtracted from total porosity and the remaining value was the percentage of air in the soil. The soil water content was measured daily at a soil depth of $30 \mathrm{~cm}$ by frequency domain reflectometry (FDR) using a Diviner probe (Diviner, 2000; Sentek Sensor Technologies, Stepney, Australia). Soil water content was also determined volumetrically (q) at a soil depth of $30 \mathrm{~cm}$ in order to calibrate the FDR soil moisture value with the actual $\mathrm{q}$. The calibration was made at the end of the study season measuring $\mathrm{q}$ and taking a FDR reading in one pot per soil type, from saturation to permanent wilting point.

\section{Soil oxygen diffusion rate}

The oxygen diffusion rate (ODR) in the soil was measured on 2 dates during the first season and on 3 dates during the second season with a Pt-electrode and oxygen diffusion meter (Eijkelkamp, Netherlands) as described by Letey and Stolzy (1964). Measurements were made during the morning with 2 irrigation pulses applied during the measurement period; the Ptelectrode was inserted.

\section{Soil and water chemical characteristics}

The soil samples were dried at $40^{\circ} \mathrm{C}$, sifted through a $2 \mathrm{~mm}$ mesh screen and weighed, then agitated for 30 min, filtered and exchangeable cations were extracted from the soil by $1 \mathrm{~N}$ amonium acetate at $\mathrm{pH}$ 7.0. The $\mathrm{pH}$ and electric conductivity (EC) were determined using the 962, 19 method (Horwitz, 2000), (EC meter model 852, Schott Gerate, Mainz, Germany). Percent of organic matter $(\mathrm{OM})$ was determined using 
the Walkley and Black method (Walkey and Black, 1934; Page, 1982). $\mathrm{Ca}, \mathrm{Mg}, \mathrm{Na}$ and $\mathrm{K}$ in the water samples were measured with an atomic absorption spectrophotometer (EAA Analyst 200, Perkin Elmer, Wellesley, Massachusetts, USA) (Page, 1982). Chloride, bicarbonates and sulfate were measured by potentiometric titration and boron by colorimetric azomethine. The $\mathrm{N}\left(\mathrm{N}-\mathrm{NO}_{3}\right.$ and $\left.\mathrm{N}-\mathrm{NH}_{4}\right)$ was determined by steam distillation methods (Sadzawka et al., 2006)

\section{Avocado tree biomass}

At the end of the study period, all plants were harvested, aerial parts were separated from the roots and the fresh weights of leaves, shoots and wood were determined with a digital balance (Shanghai SP-300, Shanghai Huade Weighing Apparatus Co., Shanghai, China). A "shoot" refers to the current season's branches and "wood" refers to the older trunk and branches. Tissues were then oven-dried at $70^{\circ} \mathrm{C}$ for 3 days (to a constant weight) and leaves, shoots and wood dry weights were determined with an electronic balance (Transcell ESW-5M, Transcell Technology, Inc. Buffalo Grove, Illinois, USA). Root density was determined for 3 replications per treatment by subsampling roots with a 9-mm diameter, 1-m long tube sampler (Split tube sampler, Eijkelkamp, Netherlands) inserted into the soil as described by Ferreyra et al., (1984, 1989). The root sample was taken at 15 $\mathrm{cm}$ from the trunk over the whole depth of the container, which was about $65 \mathrm{~cm}$. Root samples were rinsed twice with tap water and once with deionized water, separated from the soil and fresh weights were determined. Roots were then oven-dried at $70^{\circ} \mathrm{C}$ for 3 days and root dry weight and root density $\left(\mathrm{g} \mathrm{cm}^{-3}\right)$ were determined for each plant. Total root dry weight was estimated by multiplying the root density by the total soil volume in each pot.
After detaching and weighing all the leaves of each tree, approximately 300 leaves from each tree were randomly sampled and leaf area was measured with a portable leaf area meter (model LI-3000C, Li-Cor, Lincoln, Nebraska, USA). Leaf samples were also weighed with an electronic balance (Transcell ESW-5M, Transcell Technology, Inc., Buffalo Grove, Illinois, USA) and the total leaf area per tree was estimated by multiplying the area/weight ratio of the 300 sub-sampled leaves per plant by the total leaf weight per plant.

\section{Leaf size and leaf retention}

Leaves were classified as large, medium or small, with mean areas and standard deviations of $205.1 \mathrm{~cm}^{2}$ $\pm 40.6,102.5 \mathrm{~cm}^{2} \pm 47$ and $23.0 \mathrm{~cm}^{2} \pm 1.7$ for large, medium and small leaves, respectively. The number of large, medium and small leaves was manually counted two times during the second season and the average leaf area was determined each time. Ten similar shoots from the autumn vegetative flush were labeled and the total number of leaves per shoot was determined from January to March of the second season.

\section{Nutrient concentrations and contents}

After plants were harvested for biomass determination, 20 leaf samples, 2015 -cm-long pieces of seasonal shoots, $500 \mathrm{~g}$ of old wood and $200 \mathrm{~g}$ of roots per tree replication were rinsed twice in tap water, rinsed in deionized water and then dried at $70^{\circ} \mathrm{C}$ in an oven for $48 \mathrm{hr}$ until they reached a constant weight. Dry tissue samples were ground and N, P, K, Ca, Mg, $\mathrm{Mn}$ and $\mathrm{C}$ concentrations determined as described by Page (1982). Nitrogen and C concentrations were determined with a LECO CNS-2000 Macro Elemental Analyzer (Leco, Michigan, USA). Phosphorous, K, $\mathrm{Ca}$ and $\mathrm{Mg}$ concentrations were determined by dry combustion at $500^{\circ} \mathrm{C}$ until the total organic compo- 
nents were converted to ash. For P, ashed samples were analyzed with an atomic absorption spectrophotometer (Shimadzu Corporation, Kyoto, Japan) after forming a complex with molybdate-vanadate. For K, $\mathrm{Ca}, \mathrm{Mg}$ and $\mathrm{Mn}$, the ashed tissue samples were dissolved in dilute $\mathrm{HCl}(2 \mathrm{M})$ and concentrations were determined with an atomic absorption spectrophotometer (Varian SpectrAA 220 FS, Varian Techtron Pty. Limited, Victoria, Australia). For determination of total nutrient content, concentrations in each organ were multiplied by the organ dry weight.

\section{Soil pathogen determination}

At the time plants were harvested, a composite sample of each soil treatment was taken to the Phytopatology Laboratory at the Pontificia Universidad Católica de Valparaíso and screened for the presence of soil fungi. The procedure involved diluting the soil with deionized water to $0.5 \times 10^{-3} \mathrm{~g} \mathrm{~mL}^{-1}$ and placing 100 $\mathrm{mL}$ of diluted soil extract into three different selective media: APD, SPS AND MSP (Brayford, 1992).

\section{Data analysis}

The effects of treatment on leaf area, leaf size, autumn leaf retention and dry weights, nutrient concentrations and nutrient absorption were analyzed by a one-way ANOVA and mean differences were determined with a Waller-Duncan K-Ratio Test. All statistical analyses were performed using the SAS statistical software package (SAS Institute, Cary, North Carolina, USA).

\section{Results}

\section{Soil physical proprieties and water content}

The physical characteristics of each soil are summarized in Table 1. The different soil water-to-air ratios
(W/A) reflected the different physical characteristics among clay loam (T1, T2 and T3) sandy loam (T4), and sandy (T5) soils. Bulk densities were $1.43 \mathrm{~g} \mathrm{~cm}^{-3}$, $1.49 \mathrm{~g} \mathrm{~cm}^{-3}, 1.14 \mathrm{~g} \mathrm{~cm}^{-3}, 1.45 \mathrm{~g} \mathrm{~cm}^{-3}$ and $1.38 \mathrm{~g} \mathrm{~cm}^{-3}$ for T1, T2, T3, T4 and T5, respectively. Among the clay loam soils (T1, T2 and T3), in addition to differences in bulk density, there were differences in the proportion of silt in each soil, which was $25.1 \%$, $22.6 \%$ and $37.9 \%$ for $\mathrm{T} 1, \mathrm{~T} 2$ and $\mathrm{T} 3$, respectively. The soil air capacity ("in situ" macroporosity) for seasons 2005/2006 and 2006/2007 were obtained from the average volumetric soil water content (q) and total soil porosity during each season. Soil W/A was determined by dividing the average water content throughout the study period by the average soil air content.

\section{Soil oxygen diffusion rate}

Soil oxygen diffusion rate ranged from 0.51 to 0.34 ( $\mathrm{mg} \mathrm{cm}{ }^{-2} \mathrm{~min}^{-1}$ ) for $\mathrm{T} 1,0.51$ to $0.38\left(\mathrm{mg} \mathrm{cm}{ }^{-2} \mathrm{~min}^{-1}\right)$ for T2, 0.7 to $0.5\left(\mathrm{mg} \mathrm{cm}^{-2} \mathrm{~min}^{-1}\right)$ for T3, 1.05 for T4 and 0.83 to $1.36\left(\mathrm{mg} \mathrm{cm}^{-2} \mathrm{~min}^{-1}\right)$ for T5.

\section{Soil and water chemical characteristics}

Chemical characteristics of each soil and the irrigation water at the beginning of the experiment are summarized in Tables 2 and 3, respectively. Soil pH ranged between 6.1 and 7.0 and electrical conductivities ranged from 0.23 to $0.46 \mathrm{dS} \mathrm{m}^{-1}$; levels of both variables were non-limiting conditions for avocado growth (Wolstenholme, 2002; Salazar-García and Cortés-Flores, 1988). Soil nutrient content $(\mathrm{N}, \mathrm{P}$ and $\mathrm{K})$ and organic matter $(\mathrm{MO} \%$ ) differed among soil treatments at the beginning of the experiment; in general T3 had the highest levels, medium levels were found in $\mathrm{T} 2$ and $\mathrm{T} 1$ and the lowest levels were found in T4 and T5. Soils differed in their nutrients supply (Table 2), but all were within the range for adequate avocado tree productivity (Jones and Embleton, 1978). 
Table 2. Chemical characteristics of five different soils (T1-T5) at the beginning of the study period.

\begin{tabular}{|c|c|c|c|c|c|c|}
\hline Soil & pH & $E C\left(d S ~ m^{-1}\right)$ & MO (\%) & $\mathbf{N}\left(\mathrm{mg} \mathrm{kg}^{-1}\right)$ & P Olsen $\left(\mathrm{mg} \mathrm{kg}^{-1}\right)$ & $\mathrm{K}\left(\mathbf{m g ~ k g}{ }^{-1}\right)$ \\
\hline $\mathrm{T} 1$ & 6.1 & 0.23 & 1.10 & 78.23 & 60.45 & 291.4 \\
\hline $\mathrm{T} 2$ & 7.0 & 0.43 & 1.18 & 48.85 & 63.72 & 321.2 \\
\hline $\mathrm{T} 3$ & 7.1 & 0.46 & 4.16 & 83.66 & 63.50 & 393.8 \\
\hline $\mathrm{T} 4$ & 6.1 & 0.24 & 0.59 & 39.17 & 38.96 & 171.2 \\
\hline T5 & 6.6 & 0.23 & 0.29 & 54.83 & 30.32 & 182.9 \\
\hline
\end{tabular}

Table 3. Chemical characteristics of the irrigation water.

\begin{tabular}{lcc}
\hline Variable & Characteristic & Unit \\
\hline $\mathrm{pH}$ & 6.88 & \\
$\mathrm{CE}$ & 0.67 & $\mathrm{dS} \mathrm{m}{ }^{-1}$ \\
$\mathrm{Ca}$ & 4.79 & $\mathrm{meq} \mathrm{L}^{-1}$ \\
$\mathrm{Mg}$ & 1.33 & $\mathrm{meq} \mathrm{L}^{-1}$ \\
$\mathrm{Na}$ & 1.08 & $\mathrm{meq} \mathrm{L}^{-1}$ \\
$\mathrm{~K}$ & 0.05 & $\mathrm{meq} \mathrm{L}^{-1}$ \\
Sulfate & 3.07 & $\mathrm{meq} \mathrm{L}^{-1}$ \\
Bicarbonate & 3.51 & $\mathrm{meq} \mathrm{L}^{-1}$ \\
Chloride & 0.48 & $\mathrm{meq} \mathrm{L}$ \\
SAR & 0.62 & \\
\hline
\end{tabular}

\section{Plant dry weight and biomass partitioning}

Wood, shoot, root and total plant dry weight were significantly lower for trees in $\mathrm{T} 1$ than in trees in all other treatments (Table 4). Trees in T4 had the highest total dry weight as a result of greater wood, shoot, leaf and root dry weights compared with the other treatments. Trees in T3 had the lowest leaf dry weight. There was no significant difference in dry weights between trees in $\mathrm{T} 2$ and T4, with the exception of root dry weight which was higher for T4 than T2 (Table 4). Biomass partitioning ranged from $20.2 \%$ to $25.2 \%$ for wood, $12.5 \%$ to $16.8 \%$ for shoots, $26.3 \%$ to $33.8 \%$ for leaves and $29.8 \%$ to $35.2 \%$ for roots. The proportion of biomass partitioned to the roots was higher in $\mathrm{T} 4$ and $\mathrm{T} 5$ than in the other treatments (Table 4).

Table 4. Effect of soil type (treatments; Tmt) on avocado dry weight and biomass partitioning. Values represent means $(\mathrm{n}=4)$. Different letters within columns indicate significant difference among treatments (Waller-Duncan Test, $P \leq 0.1)$. A "shoot" refers to the current season's branches and "wood" refers to the older trunk and branches.

\begin{tabular}{cccccccccc}
\hline \multicolumn{3}{c}{ Dry weight $\left(\mathbf{g ~ t r e e ~}^{-1}\right)$} & \multicolumn{5}{c}{ Biomass partitioning (\%) } \\
\hline & Wood & Shoots & Leaves & Roots & Total & Wood & Shoots & Leaves & Roots \\
\hline $\mathrm{T} 1$ & $533.2 \mathrm{c}$ & $365.4 \mathrm{c}$ & $891.6 \mathrm{bc}$ & $848.1 \mathrm{c}$ & $2,638.3 \mathrm{c}$ & 20.2 & 13.8 & 33.8 & 32.1 \\
$\mathrm{~T} 2$ & $994.0 \mathrm{ab}$ & $587.6 \mathrm{ab}$ & $1,182.4 \mathrm{ab}$ & $1,174.8 \mathrm{~b}$ & $3,938.7 \mathrm{ab}$ & 25.2 & 14.9 & 30.0 & 29.8 \\
$\mathrm{~T} 3$ & $766.9 \mathrm{bc}$ & $557.1 \mathrm{abc}$ & $883.5 \mathrm{c}$ & $1,100.3 \mathrm{bc}$ & $3,307.9 \mathrm{bc}$ & 23.2 & 16.8 & 26.7 & 33.3 \\
$\mathrm{~T} 4$ & $1,061.5 \mathrm{a}$ & $691.2 \mathrm{a}$ & $1,192.5 \mathrm{a}$ & $1,592.4 \mathrm{a}$ & $4,537.7 \mathrm{a}$ & 23.4 & 15.2 & 26.3 & 35.1 \\
$\mathrm{~T} 5$ & $801.8 \mathrm{~b}$ & $491.9 \mathrm{bc}$ & $1,255.0 \mathrm{a}$ & $1,383.0 \mathrm{ab}$ & $3,931.8 \mathrm{ab}$ & 20.4 & 12.5 & 31.9 & 35.2 \\
\hline
\end{tabular}




\section{Leaf area, leaf size and leaf retention}

At the end of season 2006/2007, the total leaf area was significantly higher for trees in T4 than in T1 (Figure 1) and average leaf size was greater for trees in $T 5$ compared to trees in T3 or T1 (Figure 2). Leaf retention was consistently longer on trees in $\mathrm{T} 5$ or $\mathrm{T} 4$ than in the other treatments throughout the entire season; in these treatments (T5 and T4) a higher number of leaves developed from autumn 2006 sprouts remained on the tree until February of 2007 (Figure 3).

\section{Nutrient concentrations}

Macronutrient concentrations in roots, wood, shoots and leaves are shown in Table 5. Root nitrogen concentration was lower in $\mathrm{T} 2$ than in the other treatments. In wood, the $\mathrm{N}$ concentration was significantly lower in T1 than in T4. No differences in shoot $\mathrm{N}$ concentration were observed among treatments. Leaf $\mathrm{N}$ concentration was higher for trees in $\mathrm{T} 4$ and $\mathrm{T} 1$ than in the other treatments.

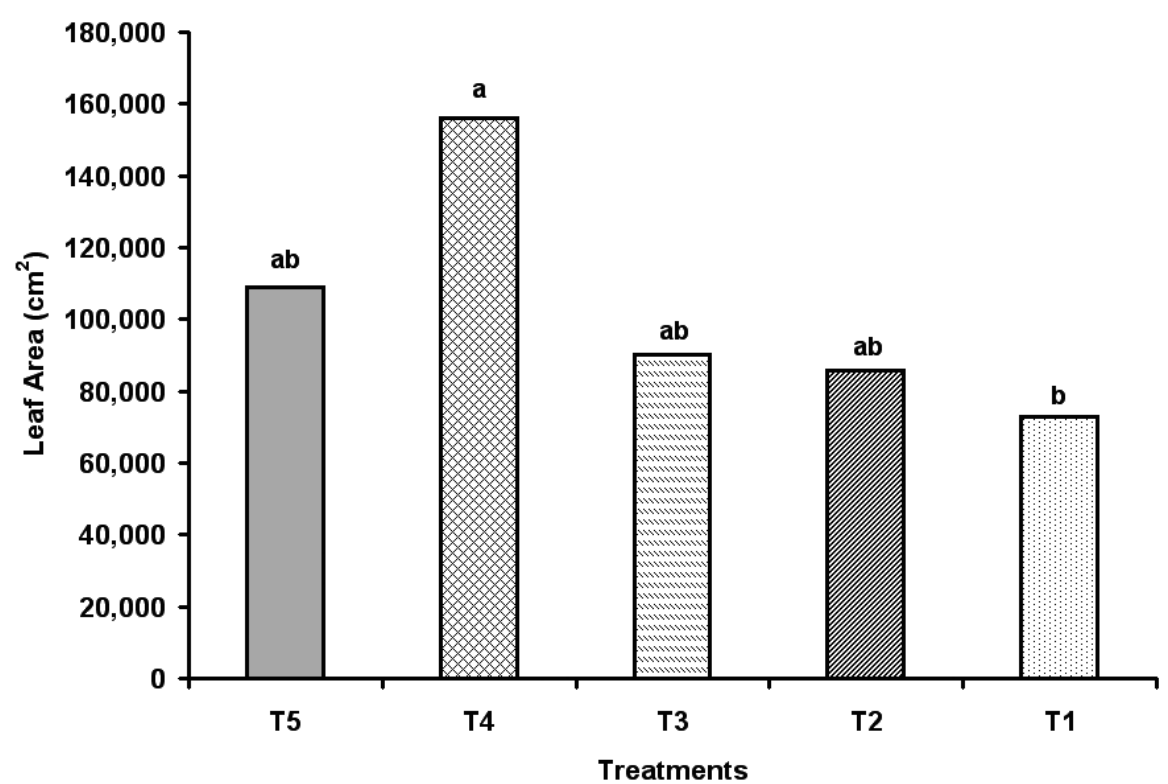

Figure 1. Avocado leaf area at the end of the 2006/2007 season. Bars indicate means. Different letters indicate significant differences (Waller-Duncan Test, $P \leq 0.1$ ). Treatments T1, T2, T3, T4, and T5 refer to two-season average W/A: $1.7,1.3,0.6,0.4$ and 0.3 , respectively. 


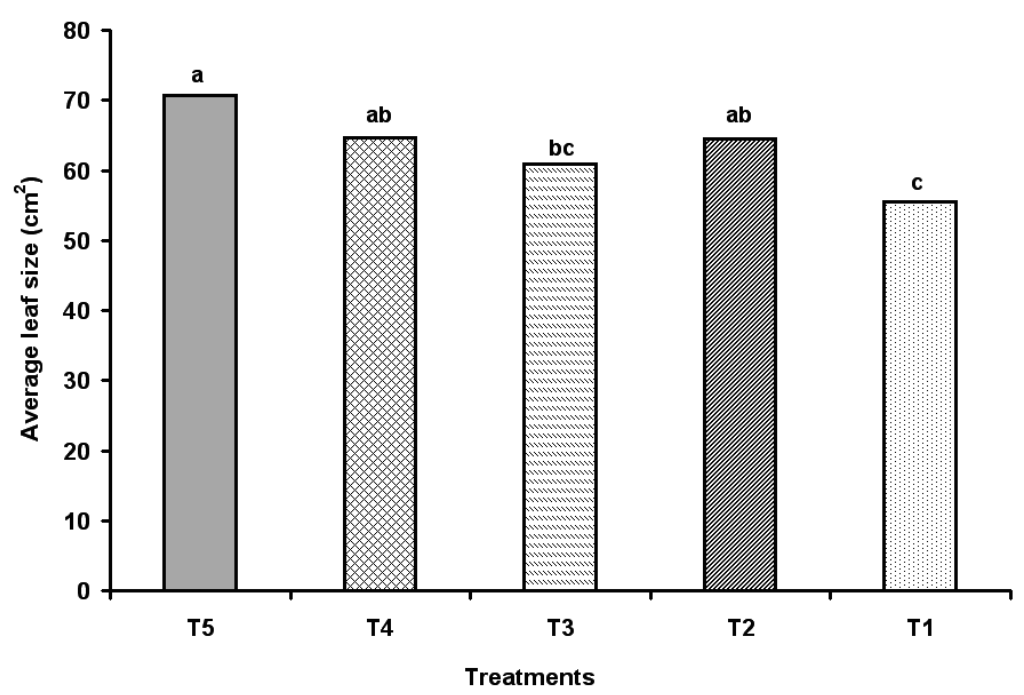

Figure 2. Average leaf size at the end of the 2006/2007 season. Bars indicate means. Different letters (a, b, c) indicate significant differences (Waller-Duncan Test, $P \leq 0.1$ ). Treatments T1, T2, T3, T4, and T5 refer to twoseason average W/A: $1.7,1.3,0.6,0.4$ and 0.3 , respectively.

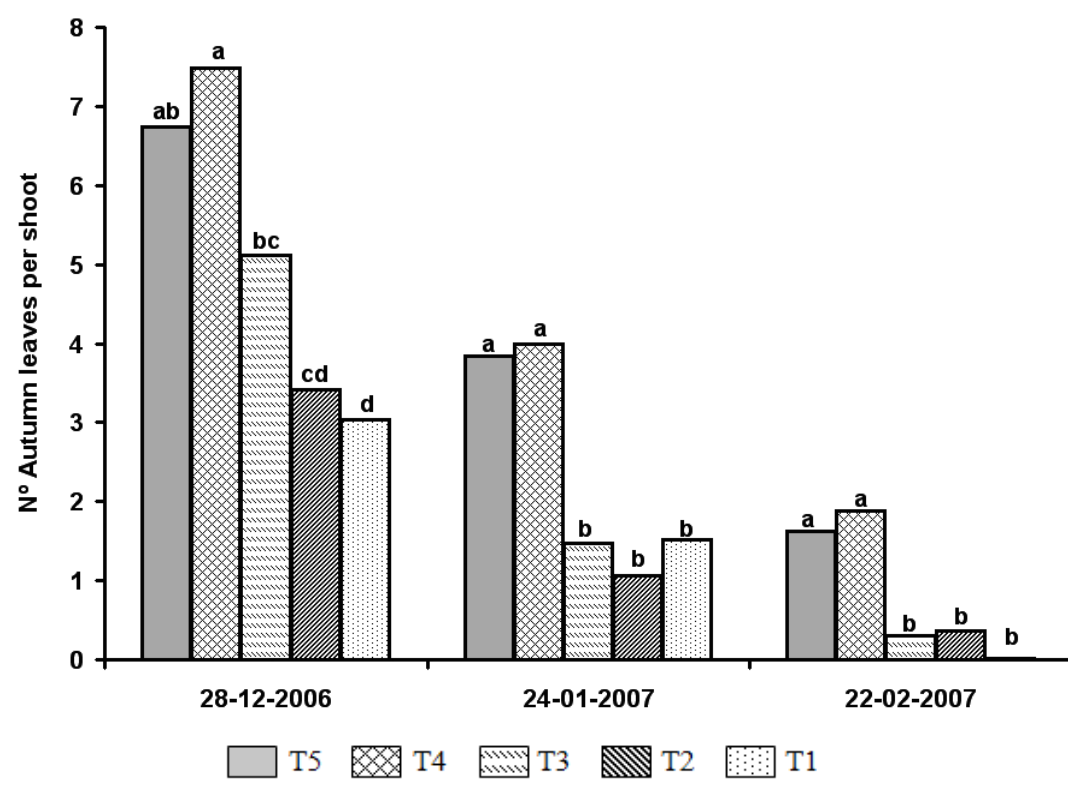

Figure 3. Number of leaves remaining on autumn shoots by December, January and February of 2006/2007. Bars indicate means $(\mathrm{n}=5)$. Different letters indicate significant differences (Waller-Duncan Test, $P \leq 0.1)$. Treatments T1, T2, T3, T4, and T5 refer to two-season average W/A: 1.7, 1.3, 0.6, 0.4 and 0.3 , respectively. 
Table 5. Effect of soils (treatments; Tmt) on macronutrients concentration in different organs of avocado trees. Values represent means $(\mathrm{n}=5)$. Different letters within columns indicate significant difference among treatments (Waller-Duncan Test, $P \leq 0.05$ ).

\begin{tabular}{|c|c|c|c|c|c|}
\hline \multicolumn{6}{|c|}{ Nutrient concentration $(\%)$} \\
\hline Element & Tmt & Roots & Wood & Shoots & Leaves \\
\hline \multirow[t]{5}{*}{$\mathrm{N}$} & $\mathrm{T} 1$ & $2.00 \mathrm{a}$ & $0.90 \mathrm{~b}$ & $2.12 \mathrm{a}$ & $3.22 \mathrm{a}$ \\
\hline & $\mathrm{T} 2$ & $1.52 \mathrm{~b}$ & $0.96 \mathrm{ab}$ & $2.18 \mathrm{a}$ & $2.72 \mathrm{~b}$ \\
\hline & $\mathrm{T} 3$ & $1.82 \mathrm{ab}$ & $1.06 \mathrm{ab}$ & $2.2 \mathrm{a}$ & $2.7 \mathrm{~b}$ \\
\hline & $\mathrm{T} 4$ & $1.90 \mathrm{a}$ & $1.16 \mathrm{a}$ & $2.26 \mathrm{a}$ & $3.0 \mathrm{a}$ \\
\hline & $\mathrm{T} 5$ & $1.92 \mathrm{a}$ & $1.08 \mathrm{ab}$ & $2.22 \mathrm{a}$ & $2.58 \mathrm{~b}$ \\
\hline \multirow[t]{5}{*}{$\mathrm{P}$} & $\mathrm{T} 1$ & $0.22 \mathrm{~b}$ & $0.10 \mathrm{~b}$ & $0.32 \mathrm{a}$ & $0.2 \mathrm{a}$ \\
\hline & $\mathrm{T} 2$ & $0.20 \mathrm{~b}$ & $0.12 \mathrm{~b}$ & $0.34 \mathrm{a}$ & $0.2 \mathrm{a}$ \\
\hline & $\mathrm{T} 3$ & $0.34 \mathrm{ab}$ & $0.12 \mathrm{~b}$ & $0.38 \mathrm{a}$ & $0.2 \mathrm{a}$ \\
\hline & $\mathrm{T} 4$ & $0.26 \mathrm{~b}$ & $0.10 \mathrm{~b}$ & $0.38 \mathrm{a}$ & $0.2 \mathrm{a}$ \\
\hline & $\mathrm{T} 5$ & $0.26 \mathrm{~b}$ & $0.18 \mathrm{a}$ & $0.32 \mathrm{a}$ & $0.2 \mathrm{a}$ \\
\hline \multirow[t]{5}{*}{ K } & $\mathrm{T} 1$ & $0.60 \mathrm{ab}$ & $1.10 \mathrm{a}$ & $1.2 \mathrm{c}$ & $1.2 \mathrm{c}$ \\
\hline & $\mathrm{T} 2$ & $0.34 \mathrm{c}$ & $0.92 \mathrm{bc}$ & $1.18 \mathrm{c}$ & $1.28 \mathrm{bc}$ \\
\hline & T3 & $0.44 \mathrm{bc}$ & $1.16 \mathrm{a}$ & $1.68 \mathrm{a}$ & $1.56 \mathrm{bc}$ \\
\hline & $\mathrm{T} 4$ & $0.62 \mathrm{ab}$ & $0.82 \mathrm{c}$ & $1.38 \mathrm{bc}$ & $1.28 \mathrm{bc}$ \\
\hline & T5 & $0.72 \mathrm{a}$ & $1.08 \mathrm{ab}$ & $1.56 \mathrm{ab}$ & $1.38 \mathrm{~b}$ \\
\hline \multirow[t]{5}{*}{$\mathrm{Ca}$} & $\mathrm{T} 1$ & $0.84 \mathrm{~d}$ & $0.40 \mathrm{c}$ & $1.08 \mathrm{~b}$ & $1.16 \mathrm{c}$ \\
\hline & $\mathrm{T} 2$ & $0.88 \mathrm{~d}$ & $0.48 \mathrm{bc}$ & $1 \mathrm{~b}$ & $1.02 \mathrm{~d}$ \\
\hline & $\mathrm{T} 3$ & $2.12 \mathrm{a}$ & $0.78 \mathrm{a}$ & $1.6 \mathrm{a}$ & $1.48 \mathrm{a}$ \\
\hline & $\mathrm{T} 4$ & $1.28 \mathrm{c}$ & $0.62 \mathrm{ab}$ & $1.14 \mathrm{~b}$ & $1.28 \mathrm{~b}$ \\
\hline & T5 & $1.52 \mathrm{~b}$ & $0.78 \mathrm{a}$ & $1.42 \mathrm{a}$ & $1.5 \mathrm{a}$ \\
\hline \multirow[t]{5}{*}{$\mathrm{Mg}$} & $\mathrm{T} 1$ & $0.28 \mathrm{bc}$ & $0.18 \mathrm{a}$ & $0.32 \mathrm{a}$ & $0.38 \mathrm{a}$ \\
\hline & $\mathrm{T} 2$ & $0.22 \mathrm{c}$ & $0.18 \mathrm{a}$ & $0.3 \mathrm{a}$ & $0.3 \mathrm{~b}$ \\
\hline & $\mathrm{T} 3$ & $0.4 \mathrm{a}$ & $0.20 \mathrm{a}$ & $0.3 \mathrm{a}$ & $0.3 \mathrm{~b}$ \\
\hline & $\mathrm{T} 4$ & $0.34 \mathrm{ab}$ & $0.18 \mathrm{a}$ & $0.32 \mathrm{a}$ & $0.3 \mathrm{~b}$ \\
\hline & T5 & $0.40 \mathrm{a}$ & $0.20 \mathrm{a}$ & $0.34 \mathrm{a}$ & $0.38 \mathrm{a}$ \\
\hline \multirow[t]{5}{*}{ C } & $\mathrm{T} 1$ & $52.03 \mathrm{a}$ & $51.13 \mathrm{a}$ & $51.83 \mathrm{a}$ & $52.2 \mathrm{a}$ \\
\hline & $\mathrm{T} 2$ & $43.93 \mathrm{a}$ & $51.00 \mathrm{a}$ & $52.5 \mathrm{a}$ & $53.17 \mathrm{a}$ \\
\hline & $\mathrm{T} 3$ & $48.47 \mathrm{a}$ & $50.97 \mathrm{a}$ & $51.27 \mathrm{a}$ & $53.27 \mathrm{a}$ \\
\hline & $\mathrm{T} 4$ & $48.97 \mathrm{a}$ & $50.53 \mathrm{a}$ & $52.2 \mathrm{a}$ & $52.73 \mathrm{a}$ \\
\hline & T5 & $52.60 \mathrm{a}$ & $51.23 \mathrm{a}$ & $52.03 \mathrm{a}$ & $52.3 \mathrm{a}$ \\
\hline
\end{tabular}


There were no differences in shoot or leaf P concentrations among treatments. However, $\mathrm{P}$ concentration was higher in wood of T3 and in roots of T5 compared with the other treatments. Leaf P concentration was higher in T5 than in T2 or T3. In wood, $\mathrm{K}$ concentration was higher in $\mathrm{T} 1$ and $\mathrm{T} 3$ than in $\mathrm{T} 2$ or $\mathrm{T} 4$, whereas shoot $\mathrm{K}$ concentration was higher in $\mathrm{T} 3$ than in T1, T2 or T4. Leaf $\mathrm{K}$ concentration was higher in $\mathrm{T} 3$ than in all other treatments. Root Ca concentration was higher in T3 than in the other treatments. In the wood, Ca concentration was lower in $\mathrm{T} 3$ than in all other treatments. In roots, $\mathrm{Mg}$ concentration was higher in T3, T4 and T5 than in T1 or T2, whereas in leaves, $\mathrm{Mg}$ concentration was highest in $\mathrm{T} 1$ and $\mathrm{T} 5$. There was no significant difference in root, wood, shoot or leaf carbon concentrations among treatments; C concentrations ranged from $43.93 \%$ to $52.6 \%$ in roots, $50.53 \%$ to $51 \%$ in wood, $51.27 \%$ to $52.5 \%$ in shoots and $52.2 \%$ to $53.27 \%$ in leaves.

Micronutrient concentrations in root, wood, shoots and leaves are shown in Table 6. In roots, $\mathrm{Cu}$ concentration was higher in T3, T4 and T5 than in $\mathrm{T} 1$ or $\mathrm{T} 2$. Wood $\mathrm{Cu}$ concentration was higher in $\mathrm{T} 5$ than in T1, T2 or T4. In shoots and leaves, no differences in $\mathrm{Cu}$ concentration were observed among treatments. Manganese concentration in shoots and leaves was lower in $\mathrm{T} 3$ than in $\mathrm{T} 1$ or $\mathrm{T} 2$, whereas there were no significant differences in root $\mathrm{Mg}$ concentration among treatments. Root Fe concentration was higher in T3 than T4. In wood, Fe levels were higher in T1, T2 and T4 than in T3, and shoot Fe concentration was higher in $\mathrm{T} 1$ than $\mathrm{T} 3$. There were no significant differences in leaf Fe concentration among treatments. In root, shoots or leaves, there was no difference in $\mathrm{Zn}$ concentration among treatments. However, in wood, $\mathrm{Zn}$ concentration was higher in T3 than T4 or T5. Wood Na concentration was highest in $\mathrm{T} 5$ and leaf $\mathrm{Na}$ concentration was higher in $\mathrm{T} 1$ than in all other treatments except T5. Root B levels were highest in T3, whereas in the other plant tissues there were not significant differences in $\mathrm{B}$ concentrations among treatments.

Table 6. Effect of soils (treatments; Tmt) on micronutrients concentration in different organs of avocado trees. Values represent means $(\mathrm{n}=3)$. Different letters within columns indicate significant difference among treatments (Waller-Duncan Test, $P \leq 0.05$ ).

\begin{tabular}{lccccc}
\hline \multicolumn{5}{c}{ Nutrient concentration (\%) } \\
\hline Element & Rmt & Roots & Wood & Shoots & Leaves \\
\hline $\mathrm{Cu}$ & $\mathrm{T} 1$ & $42.7 \mathrm{~b}$ & $8.1 \mathrm{~b}$ & $20.5 \mathrm{a}$ & $16.0 \mathrm{a}$ \\
& $\mathrm{T} 2$ & $35.1 \mathrm{~b}$ & $7.3 \mathrm{~b}$ & $15.9 \mathrm{a}$ & $13.6 \mathrm{a}$ \\
& T3 & $107.5 \mathrm{ab}$ & $9.4 \mathrm{ab}$ & $21.0 \mathrm{a}$ & $16.1 \mathrm{a}$ \\
& $\mathrm{T} 4$ & $89.8 \mathrm{ab}$ & $8.2 \mathrm{~b}$ & $21.8 \mathrm{a}$ & $16.7 \mathrm{a}$ \\
& $\mathrm{T} 5$ & $273.9 \mathrm{a}$ & $11.3 \mathrm{a}$ & $25.4 \mathrm{a}$ & $16.2 \mathrm{a}$ \\
\hline $\mathrm{Mn}$ & $\mathrm{T} 1$ & $473.8 \mathrm{a}$ & $65.4 \mathrm{a}$ & $114.0 \mathrm{a}$ & $450.3 \mathrm{a}$ \\
& $\mathrm{T} 2$ & $588.5 \mathrm{a}$ & $51.9 \mathrm{ab}$ & $106.2 \mathrm{a}$ & $378.5 \mathrm{a}$ \\
& $\mathrm{T} 3$ & $381.9 \mathrm{a}$ & $18.7 \mathrm{~b}$ & $32.5 \mathrm{~b}$ & $135.7 \mathrm{c}$ \\
& $\mathrm{T} 4$ & $478.1 \mathrm{a}$ & $37.8 \mathrm{ab}$ & $57.9 \mathrm{ab}$ & $186.5 \mathrm{bc}$ \\
\hline
\end{tabular}




\begin{tabular}{|c|c|c|c|c|c|}
\hline \multicolumn{6}{|c|}{ Nutrient concentration $(\%)$} \\
\hline Element & Tmt & Roots & Wood & Shoots & Leaves \\
\hline \multirow[t]{5}{*}{$\mathrm{Fe}$} & $\mathrm{T} 1$ & $6,9 \mathrm{ab}$ & $52.7 \mathrm{a}$ & $100.0 \mathrm{a}$ & $169.4 \mathrm{a}$ \\
\hline & $\mathrm{T} 2$ & $6,3 \mathrm{ab}$ & $54.0 \mathrm{a}$ & $81.2 \mathrm{ab}$ & $137.7 \mathrm{a}$ \\
\hline & $\mathrm{T} 3$ & $7,2 \mathrm{a}$ & $38.4 \mathrm{c}$ & $60.6 \mathrm{~b}$ & $153.7 \mathrm{a}$ \\
\hline & $\mathrm{T} 4$ & $4,3 \mathrm{~b}$ & $48.1 \mathrm{ab}$ & $83.3 \mathrm{ab}$ & $135.0 \mathrm{a}$ \\
\hline & T5 & $4,7 \mathrm{ab}$ & $42.2 \mathrm{bc}$ & $70.3 \mathrm{ab}$ & $158.5 \mathrm{a}$ \\
\hline \multirow[t]{5}{*}{$\mathrm{Zn}$} & $\mathrm{T} 1$ & $88.0 \mathrm{a}$ & $21.8 \mathrm{ab}$ & $43.2 \mathrm{a}$ & $33.1 \mathrm{a}$ \\
\hline & $\mathrm{T} 2$ & $67.6 \mathrm{a}$ & $20.7 \mathrm{ab}$ & $46.7 \mathrm{a}$ & $28.3 \mathrm{a}$ \\
\hline & $\mathrm{T} 3$ & $200.1 \mathrm{a}$ & $23.7 \mathrm{a}$ & $52.0 \mathrm{a}$ & $31.0 \mathrm{a}$ \\
\hline & $\mathrm{T} 4$ & $153.0 \mathrm{a}$ & $16.9 \mathrm{~b}$ & $44.8 \mathrm{a}$ & $32.3 \mathrm{a}$ \\
\hline & T5 & $99.5 \mathrm{a}$ & $18.8 \mathrm{~b}$ & $31.1 \mathrm{a}$ & $26.9 \mathrm{a}$ \\
\hline \multirow[t]{5}{*}{$\mathrm{Na}$} & $\mathrm{T} 1$ & $3,1 \mathrm{ab}$ & $82.3 \mathrm{a}$ & $186.7 \mathrm{a}$ & $105.4 \mathrm{~b}$ \\
\hline & $\mathrm{T} 2$ & $2,5 \mathrm{ab}$ & $135.0 \mathrm{a}$ & $185.2 \mathrm{a}$ & $98.2 \mathrm{~b}$ \\
\hline & $\mathrm{T} 3$ & $2,2 \mathrm{~b}$ & $63.1 \mathrm{a}$ & $171.3 \mathrm{a}$ & $136.4 \mathrm{a}$ \\
\hline & $\mathrm{T} 4$ & $4,2 \mathrm{ab}$ & $63.6 \mathrm{a}$ & $168.0 \mathrm{a}$ & $99.8 \mathrm{~b}$ \\
\hline & $\mathrm{T} 5$ & $4,9 \mathrm{a}$ & $63.1 \mathrm{a}$ & $184.4 \mathrm{a}$ & $107.7 \mathrm{ab}$ \\
\hline \multirow[t]{5}{*}{ B } & $\mathrm{T} 1$ & $13.2 \mathrm{c}$ & $11.1 \mathrm{a}$ & $23.7 \mathrm{a}$ & $14.7 \mathrm{a}$ \\
\hline & $\mathrm{T} 2$ & $11.9 \mathrm{c}$ & $11.1 \mathrm{a}$ & $27.9 \mathrm{a}$ & $14.6 \mathrm{a}$ \\
\hline & $\mathrm{T} 3$ & $30.1 \mathrm{a}$ & $13.7 \mathrm{a}$ & $21.5 \mathrm{a}$ & $13.9 \mathrm{a}$ \\
\hline & $\mathrm{T} 4$ & $20.7 \mathrm{~b}$ & $13.9 \mathrm{a}$ & $23.2 \mathrm{a}$ & $17.9 \mathrm{a}$ \\
\hline & $\mathrm{T} 5$ & $24.2 \mathrm{~b}$ & $13.9 \mathrm{a}$ & $23.6 \mathrm{a}$ & $18.0 \mathrm{a}$ \\
\hline
\end{tabular}

\section{Total nutrient content}

Total macro- and micronutrient contents in roots, wood, shoots, and leaves are shown in Tables 7 and 8, respectively. Root and wood nitrogen contents were higher in T4 and T5 than in T1, T2 or T3. Shoot N content was significantly higher in T4 than in T1; T4 had a higher leaf $\mathrm{N}$ content than $\mathrm{T} 3$.

Phosphorous content in roots was significantly higher in T4 than in T1 or T2. In wood, T4 and T5 had higher P content than T1 or T3. Shoot P content was lowest in $\mathrm{T} 1$ and $\mathrm{T} 5$, and highest in T4. There was a significant difference in leaf $\mathrm{P}$ content between $\mathrm{T} 4$ and $\mathrm{T} 3$.
Potassium content in roots was significantly higher in T4 and T5 than in the other treatments. The lowest wood $\mathrm{K}$ content was in $\mathrm{T} 1$ and the lowest $\mathrm{K}$ content in shoots was in $\mathrm{T} 1$ and $\mathrm{T} 2$. There was no significant difference in leaf $\mathrm{K}$ content among treatments.

The lowest root $\mathrm{Ca}$ content was in $\mathrm{T} 1$ and $\mathrm{T} 2$. In wood, Ca content was significantly higher in $\mathrm{T} 4$ and $\mathrm{T} 5$ than in T1. In leaves, Ca content was higher in T4 and $\mathrm{T} 5$ than in T1. There was no significant difference in shoot $\mathrm{Ca}$ content among treatments.

Root Mg content was higher in $\mathrm{T} 4$ and $\mathrm{T} 5$ than in the other treatments. In wood, T4 and T5 had significantly higher Ca content than $\mathrm{T} 1$. Shoot $\mathrm{Mg}$ content was higher in T4 than in T1 or T3. In leaves, T5 had 
the highest $\mathrm{Ca}$ content, which was significantly different than T3 with the lowest content.

Root carbon content was significantly higher in $\mathrm{T} 5$ than T1, T2 and T3; T4 showed a high content of C non-significantly different than T5. Carbon content in wood and shoots was significantly higher in T2, T4 and $\mathrm{T} 5$ than in $\mathrm{T} 1$ or $\mathrm{T} 3$.

For micronutrients, root contents did not differ among treatments, except for $\mathrm{Na}$ and $\mathrm{B}$. Root $\mathrm{Na}$ content was lowest in T1, T2 and T3; root B content was lowest in $\mathrm{T} 1$ and $\mathrm{T} 2$. Leaf micronutrient contents did not differ either among treatments, except for Mn. Leaf Mn contents was lower in T3 compared with T1, T2 and T4. Shoot and wood micronutrient contents did differ among treatments. There was not a clear pattern for all micronutrients, but in general T1 and/or T3 had the lowest micronutrient content in wood and shoots.

\section{Soil pathogen determination}

No significant Phytophthora sp. Colonies were found in the analyzed soil samples, indicating good control of this potentially damaging root pathogen during both measurement seasons (data not shown).

\section{Discussion}

Avocado trees in soils with lower water-to-air ratios (T4: sandy loam and T5: sandy) had greater biomass, more leaf area and longer leaf retention than trees in a heavy clay loam soil (T1), with a higher water-to-air ratio. Avocado orchards are productive on an extremely wide range of soil types with very different physical and chemical characteristics, from light sands to heavy clays and even limestone soils. They also tolerate a wide range of $\mathrm{pHs}$, from as low as 3.0 to > 8.0. The one unifying soil property that is required for good avocado growth and development is adequate soil aeration (Wolstenholme, 2002). Considering that all soils were kept at field capacity and were fertilized with the same amount of nutrients, differences in tree growth and development were presumably due to the impact of soil physical features on root oxygenation and nutrient availability or absorption.

Avocado trees grown in soils with high water-to-air ratios, particularly heavy loam clay soils (T1), had significantly less leaf, shoot and root biomass than trees in soils with lower water-to-air ratios such as sandy or sandy loam soils. Previous work has shown that the lack of oxygen in the root zone can adversely affect the shoot growth of many woody plant species by suppressing formation and expansion of leaves and internodes, or causing premature leaf senescence and abscission (Kozlowski et al., 1991; Kozlowski and Pallardy, 1997; Schaffer et al., 1992). Also, soil hypoxia reduces root growth of most plants by inhibiting root formation and branching and growth of existing roots and mycorrhizae and by inducing root decay (Kozlowski and Pallardy, 1997). Leaf abscission is a common response of avocado trees to root hypoxia (Schaffer and Ploetz, 1989; Schaffer et al., 1992; Gil et al., 2007, 2009). In many plants, root hypoxia stimulates ethylene production (Jackson 1985; Kozlowski, 1997) because under hypoxic conditions (when partial pressures of $\mathrm{O}_{2}$ in the root zone are between 0 and that of air) the conversion of the ethylene precursor 1-aminocyclopropane-1-carboxylic acid (ACC) to ethylene is actually stimulated (Jackson 1985). In recent studies, root hypoxia resulted in increased ethylene concentration in leaves (Gil et al., 2009). In the current study, soils never reached oxygen diffusion rates considered limiting for root development, but tree biomass and leaf retention were reduced when the soil water-to-air ratio was high, indicating that not only root hypoxia, but suggesting that high waterto-air ratio may increase ethylene production and thus increase abscission of organs such as leaves.

The origin, size and proportion of soil particles define the physical and chemical properties of soil which im- 
pacts the soil exploration of roots and nutrient availability and absorption. In a study of seedling hardwood species (Prunus serotina, Quercus rubra and Acer rubrum), total biomass was explained mostly by the soil in which the seedlings were grown. In that experiment, seedling trees planted in clay soil grew $64 \%$ of the size of plants that were grown in sand and sandy loam soil (Kelly et al., 2001). Also trees grown in clay loam and silty loam soils were $74 \%$ the size of trees in sand or sandy loam soil. A clear relationship between soil nutrient concentration and plant nutrient uptake was not observed.

In studies of soil texture effects on citrus, irregular flower blooms were observed on trees in soil with high percentages of clay (Dass et al., 1998). Similarly, other studies of citrus showed that low fruit yield was related to soils with heavy clay coupled with low noncapillary pore space and high soil compaction (Lai and Yin, 2003). Recently, Srivastava and Singh (2009) also reported that tree decline and poor root growth of citrus was due, at least in part, to soil compaction and poor drainage in clay soils. High bulk soil density and soil texture negatively impacted rooting in several species, including pea (e.g. Castillo et al., 1982; Bengough and Young, 1993; Pabina et al., 1998) and Quercus palustris (Watson and Kelsey, 2008).

Nagarajah (1987) studied, in irrigated vineyards, the influence of soil texture on the rooting patterns of Thompson Seedless, grapevines (Vitis vinifera). Rooting depths were $220 \mathrm{~cm}$ in coarse soil, 100 to $120 \mathrm{~cm}$ in moderately coarse soil, and 60 to $120 \mathrm{~cm}$ in fine soil. In coarse soil, roots were well spread throughout the soil profile. Smart et al., (2006) reported for the same species that physical soil properties have a greater influence on depth distributions than does genotype, even in deep fertile soils. In the present study with avocado, root biomass was significantly higher in sand and sandy loam soils. This is similar to observations by Yan et al., (2005) who found that cotton grown in sandy soil de- veloped more absorbing roots and higher root-to leafratios than those grown in heavy textured soil.

In a study conducted concurrently with the present study, Gil (2008) evaluated the effects of soil physical characteristics and water-to-air ratio on $A, T r, g s$, stem water potential (SWP) and leaf xylem abscisic acid (ABA) content in avocado trees. Although aerobic soil conditions were maintained in all treatments, trees in soil with lower water-to-air ratios (sandy loam and sandy soils) had higher $A, T r$, gs and SWP than trees in the soils with higher water-to-air ratios (heavy clay loam); also leaf xylem ABA content was higher in trees grown in heavy clay loam than in sandy loam or sandy soils. Thus the greater biomass, leaf area and leaf retention for 'Hass' avocado trees grown in soils with lower water-to-air ratios (T4: sandy loam and T5: sand) than in soil with the higher water-to-air ratios was presumably related to the greater $A, T r$, gs and SWP of trees in the soils with the lower water-to-air ratios.

Soil nutrient supply and leaf foliar nutrient concentration in trees from all treatments were within the normal range (Jones and Embleton, 1978). The chemical analysis of the irrigation water indicated that the irrigation water was of a suitable quality for normal avocado growth and development (Branson and Gustafson, 1972). Differences in nutrient uptake observed in the present study were most likely related to the increased physiological functions (leaf gas exchange and water uptake) as a result of soil aeration and nutrient movement and availability within soils related to the different physical properties of the soil.

Plant nutrient uptake is largely a function of root surface area (Kelly et al., 2001), but uptake of mobile ions such as $\mathrm{NO}_{3}$ and $\mathrm{NH}_{4}$ appear to be less responsive to root growth (Robinson and Rorison, 1983). In the present study, trees in the lower water-to-air ratios had larger root biomass and more $\mathrm{N}$ absorption (Table 7), which positively impacted tree vigor, leaf biomass, leaf area and retention. 
Table 7. Effect of soils (treatments; Tmt) on macronutrients content in the entire avocado tree and in different organs. Values represent means $(\mathrm{n}=3)$. Different letters within columns indicate significant difference among treatments (Waller-Duncan Test, $P \leq 0.05$ ).

\begin{tabular}{|c|c|c|c|c|c|c|}
\hline \multicolumn{7}{|c|}{ Macronutrient content (g) } \\
\hline Element & Tmt & Roots & Wood & Shoots & Leaves & Tree \\
\hline \multirow[t]{5}{*}{$\mathrm{N}$} & $\mathrm{T} 1$ & $15.4 \mathrm{~b}$ & $5.17 \mathrm{~b}$ & $8.33 \mathrm{~b}$ & $27.1 \mathrm{ab}$ & $56.0 \mathrm{c}$ \\
\hline & $\mathrm{T} 2$ & $18.1 \mathrm{~b}$ & $8.63 \mathrm{~b}$ & $12.8 \mathrm{ab}$ & $33.2 \mathrm{ab}$ & $72.8 \mathrm{bc}$ \\
\hline & $\mathrm{T} 3$ & $19.6 \mathrm{~b}$ & $7.53 \mathrm{~b}$ & $10.3 \mathrm{ab}$ & $22.0 \mathrm{~b}$ & $59.4 \mathrm{c}$ \\
\hline & $\mathrm{T} 4$ & $29.3 \mathrm{a}$ & $13.63 \mathrm{a}$ & $15.9 \mathrm{ab}$ & $36.5 \mathrm{a}$ & $95.4 \mathrm{a}$ \\
\hline & T5 & $31.5 \mathrm{a}$ & $9.63 \mathrm{ab}$ & $10.4 \mathrm{ab}$ & $30.0 \mathrm{ab}$ & $81.6 \mathrm{ab}$ \\
\hline \multirow[t]{5}{*}{$\mathrm{P}$} & $\mathrm{T} 1$ & $1.8 \mathrm{c}$ & $0.7 \mathrm{c}$ & $1.2 \mathrm{~d}$ & $1.8 \mathrm{ab}$ & $5.5 \mathrm{c}$ \\
\hline & $\mathrm{T} 2$ & $2.3 \mathrm{bc}$ & $1.43 \mathrm{ab}$ & $2.1 \mathrm{ab}$ & $2.3 \mathrm{ab}$ & $8.1 \mathrm{~b}$ \\
\hline & $\mathrm{T} 3$ & $3.7 \mathrm{abc}$ & $1.07 \mathrm{bc}$ & $1.8 \mathrm{bc}$ & $1.4 \mathrm{~b}$ & $7.9 \mathrm{bc}$ \\
\hline & $\mathrm{T} 4$ & $4.3 \mathrm{a}$ & $1.47 \mathrm{a}$ & $2.5 \mathrm{a}$ & $2.6 \mathrm{~b}$ & $11.0 \mathrm{a}$ \\
\hline & T5 & $3.9 \mathrm{ab}$ & $1.53 \mathrm{a}$ & $1.5 \mathrm{dc}$ & $2.2 \mathrm{ab}$ & $9.1 \mathrm{ab}$ \\
\hline \multirow[t]{5}{*}{ K } & $\mathrm{T} 1$ & $5.0 \mathrm{~b}$ & $5.5 \mathrm{~b}$ & $4.6 \mathrm{c}$ & $10.6 \mathrm{a}$ & $25.7 \mathrm{~b}$ \\
\hline & $\mathrm{T} 2$ & $4.4 b$ & $8.37 \mathrm{a}$ & $7.0 \mathrm{~cd}$ & $15.5 \mathrm{a}$ & $35.2 \mathrm{ab}$ \\
\hline & $\mathrm{T} 3$ & $4.1 \mathrm{~b}$ & $8.27 \mathrm{a}$ & $8.2 \mathrm{ab}$ & $13.0 \mathrm{a}$ & $33.6 \mathrm{~b}$ \\
\hline & $\mathrm{T} 4$ & $9.8 \mathrm{a}$ & $8.97 \mathrm{a}$ & $10.0 \mathrm{a}$ & $15.4 \mathrm{a}$ & $44.1 \mathrm{a}$ \\
\hline & $\mathrm{T} 5$ & $11.6 \mathrm{a}$ & $9.17 \mathrm{a}$ & $7.5 \mathrm{ab}$ & $16.0 \mathrm{a}$ & $44.3 \mathrm{a}$ \\
\hline \multirow[t]{5}{*}{$\mathrm{Ca}$} & $\mathrm{T} 1$ & $6.1 \mathrm{~b}$ & $2.0 \mathrm{~b}$ & $4.2 \mathrm{a}$ & $9.7 \mathrm{c}$ & $22.0 \mathrm{~b}$ \\
\hline & $\mathrm{T} 2$ & $9.2 \mathrm{~b}$ & $3.6 \mathrm{ab}$ & $6.3 \mathrm{a}$ & $12.4 \mathrm{bc}$ & $31.6 \mathrm{~b}$ \\
\hline & $\mathrm{T} 3$ & $23.8 \mathrm{a}$ & $5.6 \mathrm{ab}$ & $7.5 \mathrm{a}$ & $11.72 b c$ & $48.6 \mathrm{a}$ \\
\hline & $\mathrm{T} 4$ & $19.0 \mathrm{a}$ & $6.9 \mathrm{a}$ & $9.0 \mathrm{a}$ & $15.6 \mathrm{ab}$ & $50.5 \mathrm{a}$ \\
\hline & $\mathrm{T} 5$ & $26.8 \mathrm{a}$ & $6.8 \mathrm{a}$ & $6.4 \mathrm{a}$ & $18.47 \mathrm{a}$ & $58.5 \mathrm{a}$ \\
\hline \multirow[t]{5}{*}{$\mathrm{Mg}$} & $\mathrm{T} 1$ & $2.1 \mathrm{~d}$ & $0.8 \mathrm{~b}$ & $1.3 \mathrm{~b}$ & $3.1 \mathrm{ab}$ & $7.3 \mathrm{~b}$ \\
\hline & $\mathrm{T} 2$ & $2.6 \mathrm{~cd}$ & $1.4 \mathrm{ab}$ & 1.8 & $3.7 \mathrm{ab}$ & $9.4 \mathrm{~b}$ \\
\hline & $\mathrm{T} 3$ & $4.2 \mathrm{bc}$ & $1.3 \mathrm{ab}$ & $1.4 \mathrm{~b}$ & $2.4 \mathrm{~b}$ & $9.4 \mathrm{~b}$ \\
\hline & $\mathrm{T} 4$ & $4.9 \mathrm{ab}$ & $1.9 \mathrm{a}$ & $2.3 \mathrm{a}$ & $3.9 \mathrm{ab}$ & $13.0 \mathrm{a}$ \\
\hline & T5 & $6.17 \mathrm{a}$ & $1.8 \mathrm{a}$ & $1.5 \mathrm{ab}$ & $4.5 \mathrm{a}$ & $14.0 \mathrm{a}$ \\
\hline \multirow[t]{5}{*}{$\mathrm{C}$} & $\mathrm{T} 1$ & $550.3 \mathrm{~b}$ & $274.2 \mathrm{c}$ & $204.4 \mathrm{~b}$ & $436.4 \mathrm{a}$ & $1211.3 \mathrm{~b}$ \\
\hline & $\mathrm{T} 2$ & $483.7 \mathrm{~b}$ & $506.2 \mathrm{a}$ & $319.4 \mathrm{ab}$ & 614.9 a & $1846.3 \mathrm{a}$ \\
\hline & $\mathrm{T} 3$ & $580.2 \mathrm{~b}$ & $347.0 \mathrm{bc}$ & $243.6 \mathrm{~b}$ & $441.6 \mathrm{a}$ & $1433 \mathrm{~b}$ \\
\hline & $\mathrm{T} 4$ & $771.5 \mathrm{ab}$ & $568.2 \mathrm{a}$ & $373.9 \mathrm{a}$ & $635.2 \mathrm{a}$ & $2219.7 \mathrm{a}$ \\
\hline & $\mathrm{T} 5$ & $1075.5 \mathrm{a}$ & $433.3 \mathrm{ab}$ & $254.9 \mathrm{ab}$ & $634.8 \mathrm{a}$ & $2009.8 \mathrm{a}$ \\
\hline
\end{tabular}


Table 8. Effect of soils (treatments; Tmt) on micronutrients content in the entire avocado tree and in different organs. Values represent means $(\mathrm{n}=3)$. Different letters within columns indicate significant difference among treatments (Waller-Duncan Test, $P \leq 0.05$ ).

\begin{tabular}{|c|c|c|c|c|c|c|}
\hline \multicolumn{7}{|c|}{ Micronutrient content (mg) } \\
\hline Element & Tmt & Roots & Wood & Shoots & Leaves & Tree \\
\hline \multirow[t]{5}{*}{$\mathrm{Cu}$} & $\mathrm{T} 1$ & $30.4 \mathrm{a}$ & $4.3 \mathrm{~b}$ & $8.2 \mathrm{a}$ & $13.3 \mathrm{a}$ & $56.2 \mathrm{~b}$ \\
\hline & $\mathrm{T} 2$ & $42.4 \mathrm{a}$ & $7.4 \mathrm{ab}$ & $9.6 \mathrm{a}$ & $16.0 \mathrm{a}$ & $75.3 \mathrm{~b}$ \\
\hline & $\mathrm{T} 3$ & $118.7 \mathrm{a}$ & $6.4 \mathrm{ab}$ & $9.8 \mathrm{a}$ & $13.4 \mathrm{a}$ & $148.2 \mathrm{ab}$ \\
\hline & $\mathrm{T} 4$ & $161.9 \mathrm{a}$ & $9.2 \mathrm{a}$ & $15.4 \mathrm{a}$ & $20.2 \mathrm{a}$ & $206.7 \mathrm{ab}$ \\
\hline & T5 & $489.6 \mathrm{a}$ & $9.5 \mathrm{a}$ & $13.0 \mathrm{a}$ & $19.8 \mathrm{a}$ & $531.8 \mathrm{a}$ \\
\hline \multirow[t]{5}{*}{$\mathrm{Mn}$} & $\mathrm{T} 1$ & $357.7 \mathrm{a}$ & $34.2 \mathrm{ab}$ & $45.5 \mathrm{ab}$ & $371.7 \mathrm{a}$ & 809.1 a \\
\hline & $\mathrm{T} 2$ & $691.3 \mathrm{a}$ & $52.5 \mathrm{a}$ & $64.4 \mathrm{a}$ & $450.2 \mathrm{a}$ & $1258.3 \mathrm{a}$ \\
\hline & $\mathrm{T} 3$ & $505 \mathrm{a}$ & $12.6 \mathrm{~b}$ & $15.4 \mathrm{~b}$ & $113.8 \mathrm{~b}$ & 646.9 a \\
\hline & $\mathrm{T} 4$ & $649.8 \mathrm{a}$ & $56.0 \mathrm{a}$ & $62.1 \mathrm{ab}$ & $407.7 \mathrm{a}$ & $1175.5 \mathrm{a}$ \\
\hline & $\mathrm{T} 5$ & $779.8 \mathrm{a}$ & $31.9 \mathrm{ab}$ & $28.8 \mathrm{ab}$ & $231.6 \mathrm{ab}$ & $1072.1 \mathrm{a}$ \\
\hline \multirow[t]{5}{*}{$\mathrm{Fe}$} & $\mathrm{T} 1$ & $5005 \mathrm{a}$ & $28.1 \mathrm{~b}$ & $40.0 \mathrm{ab}$ & $140.8 \mathrm{a}$ & $5214 \mathrm{a}$ \\
\hline & $\mathrm{T} 2$ & 8495 a & $53.3 \mathrm{a}$ & $48.7 \mathrm{ab}$ & $161.4 \mathrm{a}$ & $8758 \mathrm{a}$ \\
\hline & $\mathrm{T} 3$ & 7893 a & $26.1 \mathrm{~b}$ & $28.4 \mathrm{~b}$ & $127.1 \mathrm{a}$ & 8075 a \\
\hline & $\mathrm{T} 4$ & 7296 a & $54.3 \mathrm{a}$ & $59 \mathrm{a}$ & $162.6 \mathrm{a}$ & $7571 \mathrm{a}$ \\
\hline & T5 & $7442 \mathrm{a}$ & $35.3 \mathrm{~b}$ & $35.1 \mathrm{~b}$ & $194.5 \mathrm{a}$ & $7707 \mathrm{a}$ \\
\hline \multirow[t]{5}{*}{$\mathrm{Zn}$} & $\mathrm{T} 1$ & $63.6 \mathrm{a}$ & $11.6 \mathrm{~b}$ & $17.0 \mathrm{ab}$ & $27.6 \mathrm{a}$ & $119.9 \mathrm{~b}$ \\
\hline & $\mathrm{T} 2$ & $79.5 \mathrm{a}$ & $20.6 \mathrm{a}$ & $27.7 \mathrm{ab}$ & $33.1 \mathrm{a}$ & $160.7 \mathrm{ab}$ \\
\hline & $\mathrm{T} 3$ & $235.6 \mathrm{a}$ & $16.1 \mathrm{ab}$ & $24.5 \mathrm{ab}$ & $25.6 \mathrm{a}$ & $301.7 \mathrm{ab}$ \\
\hline & $\mathrm{T} 4$ & $236.7 \mathrm{a}$ & $18.9 \mathrm{a}$ & $32.71 \mathrm{a}$ & $38.9 \mathrm{a}$ & $327.3 \mathrm{a}$ \\
\hline & $\mathrm{T} 5$ & $160.4 \mathrm{a}$ & $15.7 \mathrm{ab}$ & $15.9 \mathrm{~b}$ & $32.6 \mathrm{a}$ & $224.7 \mathrm{ab}$ \\
\hline \multirow[t]{5}{*}{$\mathrm{Na}$} & $\mathrm{T} 1$ & $2062 \mathrm{~b}$ & $44.6 \mathrm{a}$ & $72.5 \mathrm{c}$ & $87.8 \mathrm{a}$ & $2267 \mathrm{~b}$ \\
\hline & $\mathrm{T} 2$ & $3111 \mathrm{~b}$ & $153.4 \mathrm{a}$ & $110.3 \mathrm{ab}$ & $113.2 \mathrm{a}$ & $3488 \mathrm{~b}$ \\
\hline & $\mathrm{T} 3$ & $2248 \mathrm{~b}$ & $42.5 \mathrm{a}$ & $79.3 \mathrm{bc}$ & $116.5 \mathrm{a}$ & $2486 \mathrm{~b}$ \\
\hline & $\mathrm{T} 4$ & $7080 \mathrm{a}$ & $69.4 \mathrm{a}$ & $118.4 \mathrm{a}$ & $120.8 \mathrm{a}$ & 7388 a \\
\hline & T5 & $7880 \mathrm{a}$ & $53.4 \mathrm{a}$ & $91.4 \mathrm{abc}$ & $131.4 \mathrm{a}$ & $8156 \mathrm{a}$ \\
\hline \multirow[t]{5}{*}{ B } & $\mathrm{T} 1$ & $9.1 \mathrm{~b}$ & $6.1 \mathrm{c}$ & $9.3 \mathrm{c}$ & $12.3 \mathrm{a}$ & $36.7 \mathrm{c}$ \\
\hline & $\mathrm{T} 2$ & $14.5 \mathrm{~b}$ & $10.5 \mathrm{abc}$ & $16.6 \mathrm{ab}$ & $16.8 \mathrm{a}$ & $58.4 \mathrm{~b}$ \\
\hline & $\mathrm{T} 3$ & $31.8 \mathrm{a}$ & $9.3 \mathrm{bc}$ & $10.2 \mathrm{bc}$ & $11.3 \mathrm{a}$ & $62.6 \mathrm{~b}$ \\
\hline & $\mathrm{T} 4$ & $31.3 \mathrm{a}$ & $15.8 \mathrm{a}$ & $16.7 \mathrm{a}$ & $21.6 \mathrm{a}$ & $88.4 \mathrm{a}$ \\
\hline & T5 & $39.2 \mathrm{a}$ & $11.9 \mathrm{ab}$ & $11.7 \mathrm{abc}$ & $22.3 \mathrm{a}$ & $84.9 \mathrm{a}$ \\
\hline
\end{tabular}


In the present study, $\mathrm{P}$ absorption by trees in heavy clay loam soil (T1) with a high water-to-air ratio, was about half that of trees in sandy loam or sandy soils, which was most likely related to greater root biomass of trees in low water-to-air ratio than in the clay loam soil. A greater root biomass or root length greatly influences the acquisition of nutrients such as $\mathrm{P}$ that diffuse slowly in the soil (Olsen et al,. 1961; Clarkson, 1985). Availability of $\mathrm{K}$ in the soil is associated with the exploration capacity of roots but also with the $\mathrm{K}$ fixation capacity that depends on the clay type; $\mathrm{K}$ fixation is important in fine textured soils (Havlin et al., 2004). In our study, avocado trees grown in clay soils had $59 \%$ to $79 \%$ of the $\mathrm{K}$ found in trees grown in sandy soils. However, in the aerial plant organs, higher $\mathrm{K}$ concentrations were observed in plants in clay than in sandy soils (Table 5 ); the $\mathrm{K}$ concentrations found in all treatments were within the sufficiency range (1.2 to $2,0 \%)$ reported by Mickelbart et al., (2007) for avocado.

The calcium concentrations in the in roots, wood and leaves were lower in heavy loam clay soils (T1 and T2) than in the other soil treatments (Table 5). The $\mathrm{Ca}$ concentrations that we observed were consistent with those observed by Mickelbart et al., (2007); 1 to $2 \%$ of $\mathrm{Ca}^{+2}$ in avocado roots and 1 to $1.5 \%$ of $\mathrm{Ca}^{+2}$ in aerial organs. Plant roots absorb calcium by the root as $\mathrm{Ca}^{+2}$ mainly in the non-suberized tissue (Kostman et al., 2003; Franceschi and Nakata, 2005). In the present study there was a positive relationship between the amount of roots and $\mathrm{Ca}^{+2}$ uptake $(\mathrm{R}=0.61 ; \mathrm{p}=0.001$, data not shown), because in trees in heavy clay loam soils (T1) with significantly fewer roots absorbed only $38 \%$ of the $\mathrm{Ca}^{+2}$ of trees grown in sandy soil. Also, trees in sandy soils had more aerial growth (shoots and leaves) than trees in heavier soils. Therefore, the greater Ca uptake by trees in sandy soils with higher water-toair ratios was most likely an effect of the greater canopy volume and resultant higher transpiration as $\mathrm{Ca}$ is translocated through the xylem (Marschner, 2002).
Similar to observations of $\mathrm{Ca}$, trees in the sandy soil (T4 and T5) had significantly higher Mg concentrations than trees in the other soils. Deficiencies of $\mathrm{Mg}$ are frequently experienced in poorly drained sites and high $\mathrm{pH}$ soils (Jackson, 2008). The Mg concentrations in roots were in the range of those reported by Mickelbart et al., (2007) for avocado (0.2 to $0.4 \%$ ), with the lowest concentration in the soils with the higher W/A and highest concentration in trees in the soils with the lowest water-to-air ratios, which explains the $\mathrm{Mg}$ content found in whole trees of the different treatments.

Reduced absorption of macronutrients has been reported as a response of several tree species to soil flooding (Kozlowski and Pallardy, 1984). However in avocado, soil water-to-air ratios were not related to leaf N, P and K concentrations, probably because soil oxygen levels never reached hypoxic or anoxic conditions typically found in flooded soils. Avocado trees in sandy soil had high leaf $\mathrm{Mg}$ and $\mathrm{Ca}$ concentrations, which was unexpected because sandy soils generally have low natural fertility. However, $\mathrm{Ca}$ is translocated in the xylem. Therefore, the high $g s$ and $T r$ for trees in sandy soil relative to that of trees in clay soils (Gil, 2008) may explain the high leaf Ca concentration.

The high Mn concentration in leaves of trees in $\mathrm{T} 1$ and T2 may have been a result of the lower $\mathrm{O}_{2}$ of soils in these treatments. It has been reported that lack of $\mathrm{O}_{2}$ in soil enhances $\mathrm{Mn}$ uptake. When soil $\mathrm{O}_{2}$ content is low, the manganic form of $\mathrm{Mn}$ is converted to soluble manganous forms which are more available for plant uptake (Kozlowski, 1997). In flooded soil, this can result in soluble Mn concentrations reaching toxic levels (Kozlowski, 1997). Manganese toxicity is one of the most important limiting factors for crop production in many acid soils (Rengel, 2000) Mangenese toxicity is observed in soils with reducing conditions created by organic matter accumulation, compaction and/or flooding (Demirevska-Kepova et al., 2004). Dobermann and Fairhurst (2000) reported that 
the critical leaf and shoot concentrations for Mn toxicity in rice were $>800 \mathrm{mg} \mathrm{kg}^{-1}$ of dry weight. In the present study, the Mn concentrations in trees grown in higher water-to-air ratios, did not reach levels that could negatively affect tree metabolism.

\section{Conclusions}

Soil physical characteristics influence soil water-to-air ratios, and thus root growth which results in greater biomass of the aerial portions of the plant. Although soil origin affects nutrient concentrations which differs among organs, nutrient uptake is largely due to plant biomass, and thus mostly affected by the waterto-air ratio in the soil. Macro- and micronutrient concentrations in most tree tissues did not show a clear relationship to soil water-to-air ratios. However, total tissue content of $\mathrm{N}, \mathrm{P}, \mathrm{K}, \mathrm{Ca}, \mathrm{Mg}, \mathrm{C}, \mathrm{Na}$ and $\mathrm{B}$ in roots was significantly greater in treatments with low waterto-air ratios, which was probably a result of increased biomass of trees in the lower soil water-to-air ratios treatments. These results indicate that soil water-to-air ratios significantly affects growth and mineral nutrition of avocado trees and should be a considered for avocado site selection and management.

\section{Acknowledgements}

This study was financed by INNOVA-CORFO (Chile). We thank Mr. Tomás Gallardo from the Universidad del Mar and Ms. María José Pino from the Instituto de Educación Rural (IER) for their assistance with several measurements. We also thank the Soil and Plant Analysis Laboratory of the Agricultural and Forest Engineering Faculty of the Pontificia Universidad Católica de Chile for analytical support. Finally we thank Mr. Vernier Valencia (deceased) for his assistantship and help in maintaining experimental plots. This work is part of a Ph.D. thesis in Agricul- tural Science (P.M. Gil) at the Pontificia Universidad Católica de Chile, Facultad de Agronomía e Ingeniería Forestal.

\section{References}

Anderson, T., Starmer, W., Thorne, M. 2007. Bimodal root diameter distributions in Serengeti grasses exhibit plasticity in response to defoliation and soil texture: implications for $\mathrm{N}$ uptake. Functional Ecol. 21, 50 -60.

Ball, B., Smith, K. 1991. Gas movement. In: K.K. Smith KK and C. Mullins (eds.) Soil Analysis. Marcel Dekker, Inc. pp. 511-550.

Benavides, C. 1994. El suelo como un sistema físico. In: Suelos, una visión actualizada del recurso. Universidad de Chile, Facultad de Ciencias Agrarias y Forestales, Departamento de Ingeniería y Suelos, Santiago, Chile. pp. 121-152.

Bengough, A.G., Young, I.M. 1993. Root elongation of seedling peas through layered soil of different penetration resistances. Plant and Soil 149, 129-139.

Blake, G.R., Hartage, K.H. 1986. Bulk density. In: A. Klute (ed.) Methods of Soil Analysis. Physical and Mineralogical Methods. Amer. Soc. Agron., Madison, Wisconsin, USA. pp. 363-375.

Branson, R.L., Gustafson C.D. 1972. Irrigation water: A major salt contributor to avocado orchards. California Avocado Soc. Yrbk. 55, 56-60.

Brayford, D. 1992. Methods for research on soilborne phytopathogenic fungi. APS Press, St. Paul, Minnesota, USA. pp. 103-106.

Carrasco, J. 1997. Influencia de diferentes sistemas de laboreo en las propiedades físicas y químicas de un Luvisol cálcico de la meseta central de España. Ph.D. Thesis, Esc. Tec. Superior de Ingenieros Agrónomos, Universidad Politécnica de Madrid. 
Cassel, D.K., Nielsen, D.R. 1986. Field capacity and available water capacity. In: A. Klute (ed.). Methods of Soil Analysis. Physical and Mineralogical Methods. Amer. Soc. Agron., Madison, Wisconsin, USA. pp. 901-924.

Castillo, S.R., Dowdy, R.H., Bradford, J.M., Larson, W.E. 1982. Effects of applied mechanical stress on plant growth and nutrient uptake. Agron. J. 74, 526-530.

Clarkson, D. 1985. Factors affecting mineral nutrient acquisition by plants. Ann. Rev. Plant Physiol. 36, $77-115$.

Danielson, R.E., Sutherland, P.L. 1986. Porosity. In: A. Klute (ed.). Methods of Soil Analysis. Physical and Mineralogical Methods. Amer. Soc. Agron., Madison, Wisconsin, USA. pp. 443-461.

Dass, H.C., Singh, A., Vijayakumari, N., Singh A. 1998. Rootstock breeding- variation for leaf morphology in citrus rootstock hybrid progeny. Indian J. Hort. 55: 16-19.

Day, P.R. 1965. Particle fractionation and particlesize analysis. In C. A. Black (ed) Methods of Soil Analysis. Part I. Soil Sci. Soc. Amer.

Demirevska-Kepova, K., Simova-Stoilova, L., Stoyanova, Z., Hölzer, R., Feller, U. 2004. Biochemical changes in barley plants after excessive supply of copper and manganese. Environ. Exp. Bot. 52, 253-266.

Dobermann, A., Fairhurst, T. 2000. Rice, Mineral Toxicities. In Nutrient Disorders and Nutrient Management. International Rice Research Institute and Potash and Phosphate Institute of Canada. pp: $120-139$.

Ferreyra, R., Maldonado, P., Celedón, J., Gil, P.M., Torres, A., Sellés, G. 2008. Soil air content effects on the water status of avocado trees. Acta Horticulturae 72. 291-296.

Ferreyra, R., Sellés, G., Tosso, J. 1984. Efecto de diferentes alturas de aguas sobre el cultivo del pimien- to 1: Influencia de los excesos de humedad. Agric Tec (Chile) 45, 47-51.

Ferreyra, R., Tosso, J., Ruiz, R. 1989. Efecto de diferentes alturas de agua sobre el cultivo de tomate (Lycopersicum esculentum Mill) 2: Relación evotranspiración-crecimiento-nutrición. Agric Tec (Chile) 48, 268-272.

Ferreyra, R., Sellés, G., Celedón, J., Maldonado, P., Torres, A., Gil P.M. 2007a. Effect of the soil air content in the water status and development of avocado. Proc. Sixth World Avocado Congress, Viña del Mar, Chile.

Franceschi, V., Nakata. P. 2005. Calcium Oxalate in Plants: Formation and Function. Annual Review of Plant Biology 56, 41-71.

Gil, P.M. 2008. Study of avocado (Persea americana Mill) Physiological responses to soil water Different-to-air ratios and the transmission of root-toshoot electrical signals in response of soil water deficit and root hypoxia. Ph.D. Thesis, Pontificia Universidad Católica de Chile, 151 p.

Gil, P.M., Schaffer, B., Gutiérrez, S.M., Li, C. 2007. Effect of waterlogging on plant water status, leaf gas exchange and biomass of avocado. Proc. VIth World Avocado Congress, Viña del Mar, Chile, 12-16 Nov. 2007.

Gil, P.M., Gurovich, L., Schaffer, B., García, N., Iturriaga, R. 2009. Electrical signaling, stomatal conductance, ABA and Ethylene content in avocado trees in response to root hypoxia. Plant Signaling and Behavior 4, 100-108.

Havlin, J., Beaton, J., Tisdale, S., Nelson, W. 2004. Soil Fertility and Fertilizers. An Introduction to Nutrient Management. Prentice Hall, Inc., New Jersey, USA.

Horwitz, W. 2000. Official methods of analysis, $17^{\text {th }}$ Ed. AOAC International, 2000. Gaithersburg, MD, USA. 
Jackson, M.B. 1985. Ethylene and responses of plants to soil waterlogging and submergence. Ann. Rev. Plant Physiol. 36, 145-174.

Jackson, R. 2008. Wine Science Principles and Applications. Third Edition. Academic Press, San Diego, California, USA.

Jones,W.W., Embleton, T.W. 1978. Leaf analysis as a guide to avocado fertilization. In H.M. Reinsenauer (ed.). Soil and Plant-Tissue Testing in California. Division of Agricultural Science, University of California, USA.

Kelly, J.M., Scarbrough, J.D., Mays, P. A. 2001. Hardwood seeding root and nutrient parameters for a model of nutrient uptake. J. Environ. Qual. 30, 427-39.

Kostman ,T., Franceshi, V., Nakata, P. 2003. Endoplasmic reticulum sub-compartments are involved in calcium sequestration within raphide crystal idioblasts of Pistia stratiotes. Plant Science 165, 205-212.

Kozlowski, T.T. 1997. Response of woody plants to flooding and salinity. Tree Physiol Monograph 1, $1-29$.

Kozlowski, T.T., Pallardy, S.G. 1984. Effects of flooding on water, carbohydrate and mineral relations. In: Flooding and plant growth. T.T. Kozlowski (ed.). Academic Press, Orlando, Florida, USA, pp. 165-193.

Kozlowski, T.T., Pallardy, S.G. 1997. Physiology of woody plants. Academic Press, San Diego, California, USA.

Kozlowski, T.T., Kramer, P.J., Pallardy, S.G. 1991. The physiological ecology of woody plants. Academic Press, San Diego, California, USA.

Labanauskas, C.K., Stolzy, L.H., Zentmyer, G.A. 1978. Rootstock, soil oxygen, and soil moisture effects on growth and concentration of nutrients in avocado plants. Calif. Avo. Soc. Yrbk. 62, 118-125.
Lai L. and Yin M. 2003. Variation of Plant Root/Leaf Ratio as Soil Physics or Atmospheric Conditions Changes: Coordination between Water Losing Potential of Shoot and Water Extracting Ability of Root. Chinese ecosystem research networks No 11a, datum road Beijing 100101 P. R. China.

Letey, J. 1961. Aeration, compaction and drainage. Calif Turfgrass Cult. 11, 17-21.

Marschner, H. 2002. Mineral Nutrition of Higher Plants. Academic Press, London.

Menge, J.A., Marais, L.J. 2000. Soil Environmental factors and their relationship of avocado root rot. Subtropical Fruit News 8, 1-11.

Mengel, K., Kirkby, E.A. 2001. Principles of Plant Nutrition. Kluwer Academic Publishers, Dordrecht. 849 pp.

Mickelbart, M., Melser, S., Arpaia, M.L. 2007. Salinity-induced changes in ion concentrations of Hass avocado trees on three rootstocks. J. Plant Nutr. 30, 105-122.

Nagarajah, S. 1987. Effects of soil texture on the rooting patterns of Thompson seedless vines on own roots and on Ramsey rootstock in irrigated vineyards. Am. J. Enol. Vitic. 38, 54-59.

Olsen, S., Watanabe, F., Danielson, R. 1961. Phosphorus absorption by corn roots as affected moisture and phosphorus concentration. Soil Sci. Soc. Amer. J. 25, 289-294.

Pabina, J., Lipiecb, J., Włodeka, S., Biskupskia A., Kausc, A.1998. Critical soil bulk density and strength for pea seedling root growth as related to other soil factors. Soil and Tillage Research 46, 203-208.

Page, A.L.1982. Methods of Soil Analysis. Part 2. Chemical and Microbiological Properties, 2nd Edition, Madison, Wisconsin, USA.

Rengel, Z. 2000. Uptake and transport of manganese in plants. In: A. Sigel and H. Sigel (eds.). Metal 
Ions in Biological Systems, Marcel Dekker, New York, pp. 57-87.

Robinson, D., Rorison, J. 1983. Relationships between root morphology and nitrogen availability in a recent theoretical model describing nitrogen uptake from soil. Plant Cell Environ. 6, 641-648.

Sadzawka R., A. Carrasco, R. Grez., M.L. Mora, H. Flores y A. Neaman. 2006. Métodos de análisis de suelos recomendados para los suelos de Chile. Revisión 2006. Serie Actas Instituto de Investigaciones Agropecuarias No. 34, 164 p.

Santibáñez F, Uribe M. 1990. Atlas agroclimático de la V región y región Metropolitana. Santiago, Chile: Ministerio de Agricultura, Chile.

Scandellari, F., Ventura, M., Gioacchini, P., Vittori Antisari, L. Tagliavini, M. 2010. Seasonal pattern of net nitrogen rhizodeposition from peach (Prunus persica (L.) Batsch) trees in soils with different textures. Agric., Ecosystems Environ. 136, 162-168.

Schaffer, B. 1998. Flooding responses and water-use efficiency of subtropical and tropical fruit trees in an environmentally-sensitive wetland. Ann. Bot. $81,475-481$.

Schaffer, B., Ploetz, R.C. 1989. Net gas exchange as damage indicator for Phytophthora root rot of flooded and non-flooded avocado. HortScience 24, 653-655.

Schaffer, B., Whiley, A.W. 2002. Environmental physiology. In: A.W. Whiley, B. Schaffer, B.N. Wolstenholme (eds) Avocado: Botany, Production and Uses, CABI Publishing, Wallingford, U.K., pp. 135-160.

Schaffer, B., Andersen, P.C., Ploetz, R. C. 1992. Responses of fruit crops to flooding. In: J. Janick (ed.). Hort Reviews, AVI Publishing Co., Inc., Westport, Connecticut, USA. pp. 257-313.

Slowick, K., Labanauskas, C. K., Stolzy, L. H., Zentmyer, G. A. 1979. Influence of rootstock on, soil oxygen and soil water on the uptake and translocation of nutrients in young avocado plants. J. Amer. Soc. Hort. Sci. 104, 172-175.

Smart, R., Schwass, E., Lakso, A., Morano, L. 2006, Grapevine rooting patterns: A comprehensive analysis and a review. Am. J. Enol. Vitic. 57, 89-104.

Srivastava, A., Singh, S. 2009. Citrus Decline: Soil Fertility and Plant nutrition. J. Plant Nutr. 32, 197-245.

Stolzy, L. H., Zentmyer, G. A., Klotz, L.J., Labanauskas, C.K. 1967. Oxygen diffusion, water and Phytophthora cinnamomi in root decay and nutrition of avocados. Proc. Amer. Soc. Hort. Sci. 90, 67-76.

Valoras, N., Letey, J., Stolzy, L.H., Frolich, F. 1964. The oxygen requirements for root growth of three avocado varieties. Amer. Soc. for Hort. Sci. 85, 172-178.

Walkley A. and Black I.A. 1934. An examination of Degtjareff method for determining soil organic matter and a proposed modification of the chromic acid titration method. Soil Sci. 37: 29-38.

Wolstenholme, B.N. 2002. Ecology: climate and the edaphic environment. In: Avocado: Botany, Production and Uses. A.W. Whiley, B. Schaffer, B.N. Wolstenholme (eds). CABI Publishing, Wallingford, UK (in press). pp. 71-99.

Vetterlein, D., Szegedi, K., Stange, F., Jahn, R. 2007. Impact of soil texture on temporal and spatial development of osmotic - potential gradients between bulk soil and rhizosphere. J. Plant Nutr. Soil Sci. 170, 347-356.

Watson, G.W., Kelsey, P. 2006. The impact of soil compaction on soil aeration and fine root density of Quercus palustris. Urban For. Urban Green. 4, 69-74.

Yan, L., Xu, H., Cohen, S. 2005. Long-term hydraulic acclimation to soil texture and radiation load in cotton. Plant Cell Environ. 28, 492-499. 